\title{
Capital Flows to BRICS Countries During 2000-2010
}

\author{
Vanessa da Costa Val Munhoz ${ }^{*}$ \\ Larissa Naves de Deus ${ }^{\dagger}$ \\ Vanessa de Paula Pereira ${ }^{\ddagger}$
}

\begin{abstract}
The objective of this paper is to analyze the dynamics of financial flows towards the BRICS in the period 2000-2010. Particularly, the paper examines the impacts of the capital controls adopted by each economy on the movements of specific types of capital registered in their financial accounts. The idea is to show that, regarding financial dynamics, the economies of the BRICS present peculiar characteristics that should be taken into account in the formulation of strategies for global financial regulation. To accomplish this goal, Minsky's theoretical framework is used as background; and the methodology adopted is the case study of the volatility of financial accounts of each country through Generalized Autoregressive Conditional Heteroskedasticity models (GARCH). The empirical findings connected to the capital account regulations of each country analyzed suggest that the lower volatility of financial flows can be associated with the adoption of different strategies to manage capital flows.
\end{abstract}

Key-words: BRICS, Financial Flows, Capital Controls.

JEL classification: F32, F34, F36.

*Instituto de Economia e Relações Internacionais, Universidade Federal de Uberlândia, vanessa.costaval@ufu.br

† Doutoranda do Programa de Pós-Graduação em Economia da Universidade Federal de Uberlândia.

‡ Analista Financeira da Primo Investment Fund. 


\section{Introduction}

Although the movement of international capital has been a subject of great importance and very much a part of the debate among economists for decades, recently the interest in the negative impacts of unregulated capital flows in developing countries was strongly rekindled. The discussion took place especially in academia, after the outbreak of the subprime crisis in the United States, which developed into a global crisis in 2008. After the systemic sudden stop resulting from the crisis, there has been a strong recovery in capital inflows to emerging market economies. As a consequence, there has also been a reassessment of capital controls.

Control or management of capital flows may be needed in order to avoid reversions in financial flows - the famous sudden stops. For Forbes (2007a, 2007b), capital controls could potentially lower the costs of free capital movement, such as the appreciation of domestic currency, the decline in export competitiveness, the Dutch disease and the inefficiency of investments due to market distortions. Moreover, following Klein (2012), there is a recent theory that highlights the prudential role of capital controls whereby temporary, pro-cyclical, well targeted controls contribute to financial stability ${ }^{1}$. Therefore, evolving practices and prescriptions make this an opportune time to reconsider the role of capital controls.

Given the justified use of capital controls and the current boom of capital inflows to emerging economies, it is important to discuss the behavior of the financial flows to these economies and their destabilizing potential. The strong foreign capital inflows have brought about macroeconomic imbalances and high financial fragility to several receiving economies. Some of the countries that compose the BRICS have suffered such experiences. Brazil, India and South Africa have gone through recurring current account deficits and strong exchange rates appreciations as a consequence. In such cases, foreign capital is essential to finance the growing current account deficits. At the same time, Russia and China, which maintain strong Balance of Payments positions without suffering from the deficits mentioned, also faced asset bubbles during the financial crisis in 2008. Therefore, it is relevant to examine the dynamics of financial flows to these economies, in order to show where they stand in terms of external vulnerability and to understand the role of the capital controls adopted.

The study of the BRICS economies is justified by their economic potential, which results from the size of their GDPs, geographical territories and populations, despite the problems that arise from social differences. Besides, these countries have presented a faster economic recovery from the Financial Crisis of 2008 than developed countries. However, it is important to highlight a critical perspective relative to the creation of this group of countries. Indeed, the four original countries are different in many ways, especially with regard to their financial structures, as we will see in section 3. For Kregel (2009), this category is also an invention of developed countries' financial institutions, such as Goldman Sachs (O'Neill, 2001), seeking intermediation profits.

It should also be noted that some studies investigate the relationship between exchange rate regime, capital account convertibility and economic performance (such as Paula and Barcelos, 2011 and Ferrari Filho and Paula, 2006). Therefore, there is plenty of room for discussion of the dynamics of capital flows to BRICS countries, a topic which has been little explored in the economics literature.

The present study aims to help fill this gap, analyzing the capital flows registered in the Balance of Payments of the BRICS from 2000 to 2010 (a period that includes the years prior to the 2008 crisis and the subsequent recovery), in order to understand the dynamics of capital flows directed towards emerging economies. Focusing on the data for the financial accounts of

${ }^{1}$ See Jeanne (2012). 
each country, we intend to examine the categories of capital inflows and verify whether the resources directed to these economies are speculative, that is, capital inflows with a shortterm bias.

The methodology adopted is the case study of the financial accounts of each country. The analysis will be based on detailed examinations of the financial accounts and sub-accounts of the Balance of Payments, with the main focus on the composition and nature of the capital flows. Moreover, we will use Generalized Autoregressive Conditional Heteroskedasticity models (GARCH) to analyze the volatility of the financial accounts, in order to detect the times when there are peaks of volatile capitals in these economies. It must be noted that these accounts will be examined in detail, so that direct foreign investment, portfolio investments, other investments and derivatives can all be investigated from both the asset and the liability side.

To accomplish its objective, the paper is divided into three sections besides this introduction. Section 2 is dedicated to the analysis of the recent financial dynamics in emerging countries, considering the theory of Hyman Minsky. Section 3, which analyzes the recent experience of each of the BRICS in the selected period, is divided into three parts. The first part briefly presents the external insertion of the countries, the second shows a detailed examination of the financial flows to the BRICS, and the third presents capital account regulations in BRICS, including a review of the literature on the importance of capital control policies and the capital control measures adopted by the BRICS. In the final remarks we briefly compare these experiences and draw some conclusions.

\section{The recent financial dynamics in emerging countries based on Minsky's Theory}

In recent years, especially from the 1990s onward, emerging economies have adopted financial liberalization measures. Financial liberalization is generally characterized by the free movement of capital among several countries, by the predominance of financial relations over productive relations in the economy, by financial innovations that facilitate the attraction and application of funds for several purposes, by the deregulation of the financial sector and by the appearance of institutional investors. Altogether, such measures establish the integration of a country's domestic financial market to the global financial market.

Financial liberalization measures bring along the question of the instability that nowadays undermines international financial and monetary relations. Plihon (1995) points out that such instability is directly related to the process of financial globalization, which strengthens the speculative logic.

The theory of financial resources in a fragile financial environment was particularly developed by Hyman Minsky. The author's contributions can be considered for the analysis of the cyclical fluctuations of financial conditions that endogenously generate instability and fragility in a context of financial liberalization. At present, many researchers (Kregel, 2004 and 2014; Wolfson, 2014; among others) indicate the Minskyan analysis as the most appropriate to explain the current international crisis. Minsky $(1982,1986)$ clarifies the hypothesis of capitalism's financial fragility ${ }^{2}$ by showing how crises are endogenously generated in monetary economies and how they originate from the expansion phase of the economies' own business

\footnotetext{
${ }^{2}$ Here it is important to differentiate financial fragility from financial instability as stated by Minsky. Financial fragility is a prerequisite for financial instability. Minsky's financial instability hypothesis is part of an endogenous dynamic involving increased financial fragility during the upward phase of the cycle. Fragility increases in periods of prosperity due to a financial structure dominated by Speculative and Ponzi finance in relation to Hedge finance.
} 
cycle. Thus, the keynote of the Minskyan approach is that the financial side is emphasized at the expense of the productive side, so periods of financial market instability are inherent to the operation of the capitalist economy.

With the intent to describe the dynamics of the financial cycles, the above mentioned author shows how, at moments of expansion, there is a diversification of the financial instruments available, as a result of the favorable market conditions, facilitating households', companies' and governments' access to financing. As a consequence, economic agents move from a stable economic behavior, which Minsky calls Hedge positions (when the cash flows arising from the liability structure can be fully met out of the prospective income flows from assets), to adopt Speculative positions (when it is possible to meet interest payments, but the principal has to be rolled-over until some date in the future, at which time income flows are expected to rise). These positions may later turn into ultra-speculative behavior (Ponzi positions), creating a potential risk of instability.

Besides increasing the indebtedness of economic agents, and thus expanding the potential fragility of the economies, the current financial innovations are capable of extending the expansive cycle and, eventually, delaying the crises. But, at the same time, they increase potential fragility, especially of peripheral economies whose access to loans in local currency is limited ${ }^{3}$.

At this point it is worth mentioning the monetary asymmetry that characterizes the international financial and monetary system, as pointed out by Prates $(2005)^{4}$. In this sense, the author indicates that there is a key currency in the international monetary system, the dollar, which is the safest asset, with the highest convertibility and liquidity in the economy. The so-called convertible currencies are the currencies of the remaining central countries, which are used to denominate contracts and are demanded as an international store of value (though to a lesser extent than the dollar). However, the currencies of peripheral countries are not convertible, "(...) these countries, in general, are incapable of issuing foreign debt denominated in their own currency" ${ }^{5 \prime}$. (Prates, 2005, p.274).

The Minskyan approach can be used to analyze the increase in capital flows to peripheral countries, mainly after the process of trade and financial opening which started at the beginning of the 1990s. Some of these flows are direct investments, which are a more stable type of capital flow, and the remaining flows belong to equity investors who seek more profitable applications, especially at times of high international liquidity. One of the main aspects of this process is that, at these moments, the volume of short-term inflows may be greater than the needs of the Balance of Payments of these economies.

Along with the massive capital inflows comes the illusion of financial prosperity among agents in peripheral economies. However, these inflows result in local currency appreciation, which has a negative impact on economic growth. Furthermore, all transactions rely on the agents' expectations in such a way that, if those expectations change, there may be an abrupt reversal in the capital flows attracted to these economies. The result is a climate of distrust and uncertainty among investors and soon the economy is caught in a vicious circle brought about by speculation (PLIHON, 1995).

\footnotetext{
${ }^{3}$ According to Fritz, Prates and Paula (2014), the currencies of peripheral emerging economies have a lower liquidity premium than the currencies of advanced economies.

${ }^{4}$ Prates (2005) also defines the asymmetry of the international financial and monetary, which refers to the determinants of capital flows directed to emerging economies and the size of these flows.

${ }^{5}$ Translated by the author.
} 
Indeed, a significant part of the investors that seek alternative applications tend to be speculators and, as such, are willing to buy riskier assets. However, at the same time, these investors demand extra yield to compensate for the risk. Thus, at times of favorable expectations these capitals are attracted to peripheral economies because they offer much higher interest rates than those observed in central countries. The easy access to international capital accelerates indebtedness in foreign currency; it also increases the risk of financial fragility of countries with a fast-growing demand for strong currency to make future financial payments (interest and amortization). On the other hand, at moments of negative expectations there is a sharp drop in resources, which is evidence of the financial fragility and has instant negative impacts on the Balance of Payments. Furthermore, it can be noted that the more flexible the debt instruments, the faster the reversal. According to Minsky's approach $(1986)^{6}$, the speed of the sudden reversal of capital flows, to which peripheral countries are subject, depends on how many Ponzi-scheme investors there are in the economy.

Another point worth mentioning is that funds destined to riskier assets are only a small part of the total; most investors seek assets that offer more stability. In other words, capital flows to peripheral economies represent only a small fraction of global financial assets. To a large extent, the flow of resources toward peripheral economies follows the rapid expansion of liquidity in major central countries.

Therefore, the decisions made by the economic agents are related to the monetary policy of these countries, especially the US, and to the actions of the main asset buyers, facts that are beyond the control of peripheral economies. Akyüz (2011) points out that one of the common characteristics of the historical boom and bust cycles of capital flows to emerging economies is that they all started at moments of rapid expansion of international liquidity and low interest rates in major reserve-issuing countries, notably the US.

Following this line of analysis, the underlying argument of this paper is that in the case of peripheral countries, in times of high liquidity the attraction of foreign capital with a shortterm bias increases the potential for financial instability, as the demand for strong currency grows. Another fundamental aspect is that what matters for the analysis of financial fragility is the debt profile. The greater the need for continuous renegotiation, the higher the instability potential, as financial conditions may have changed at each debt rollover. The higher the weight of short term capitals on the Balance of Payments, the greater the instability risk faced by the country, as these resources may leave at any change of events related to the dynamics of the global financial market, which is beyond the control of the country receiving these resources. Because part of this capital directed to peripheral countries searches for speculative profits, the flows' volatility itself may have a negative impact on agents' expectations, which in turn may result in abrupt reductions in the availability of resources, with impacts on interest and exchange rates.

Therefore, when expanded to the country level, the Minskyan idea that crises are inherent to capitalist economies could gain strength with the analysis of the free flows of international capital that are typical of the current integrated financial markets. According to

\footnotetext{
${ }^{6}$ Minsky's analysis was basically associated with closed economies; however, some studies have tried to expand the same analysis to exchange rate crises in several economies, especially peripheral ones (e.g. Akyüz, 1998; Kregel, 1998; Dymski, 1999; Paula and Alves Jr., 1999; Arestis and Glickman, 2002; Foley, 2003; Tonveronachi, 2006, among others). These papers treat countries as economic units, which is close to the categorization of vulnerability developed by the author. They also create measures for vulnerability and show how, through the recent economic cycles, these economies can suffer an exchange rate crisis. Paula and Alves Jr. (1999), for example, describe an external financial fragility index, which is built on the concept of financial fragility developed by Hyman Minsky, expanding his financial fragility hypothesis to the country level, as if it were a large firm.
} 
Grabel (2003), financial integration poses several risks to emerging economies: the monetary risk, the risk of capital flight, the risk of financial fragility, the risk of contagion and the sovereign risk. In an attempt to mitigate these risks, many nations have adopted capital control measures to regulate the negative effects of cross border capital volatility. Based on the Minskyan theory, which indirectly deals with these risks faced by the economies, and on the observations made in the present section, the behavior of the capital flows to the BRICS will be analyzed next.

\section{The BRICS}

The term BRIC was created by the economist Jim O'Neill, analyst of the Goldman Sachs group, in the report entitled Building Better Global Economic BRICS (O' Neill, 2001). The original idea was to contemplate the four biggest emerging economies in the world, which are Brazil, Russia, India and China. In 2003, another report by the Goldman Sachs group pointed out that in the next fifty years the combined gross domestic product of the BRIC countries would surpass the combined gross domestic product of the G-6 nations (The United States of America, England, Japan, France, Germany and Italy).

Therefore, the idea of the creator of the acronym BRIC was that those countries had similar features, as they presented higher economic growth rates in comparison to other emerging countries. At present, Brazil, Russia, India and China represent about $40 \%$ of the expansion of the Global Gross Domestic Product, according to a report by the BRICS Policy Center (2011). In April 2011, during the III BRIC Summit, South Africa was admitted to this group of countries, aiming to increase its influence on global governance. Thus the group was renamed BRICS.

There are many differences among BRICS countries. But, in terms of macroeconomic policy, an important characteristic is that China, India and Russia have managed exchange rate regimes, with limited capital account convertibility. Brazil and South Africa, on the other hand, follow a less interventionist exchange rate policy and have very open capital accounts, which has resulted in higher exchange rate volatility and a poorer economic performance. In spite of these differences and the critical perspective relatively to the creation of this group, as pointed out in the introduction, a common characteristic of the BRICS is the strong attraction of foreign direct investment (FDI). According to Sobeet (2012), the BRICS economies are the preferred destination of FDI, with a $21.1 \%$ increase in inflows in 2011.

Regarding the main focus of this paper - the financial side - we can divide the group into two subsets. Firstly, we have China and India, which have relatively closed state-controlled capital markets; followed by Brazil, Russia and South Africa, which are more open to foreign trade and financial flows and have a mixture of state and private sector control of capital markets, according to Kregel (2009). In fact, China is an extreme case in the group, as in terms of capital account management it is a typical example of strong regulations, whereas India would be classified as moderate.

China and India adopted a development strategy based on domestic industrialization (manufacturing and services) oriented towards exports, whereas Brazil, Russia and South Africa follow export strategies aimed at productive structures that are guided by international comparative advantages. The latter subset has experienced exchange rate crises and financial crises that are usually accompanied by high inflation, unlike the first group. Finally, the latter subset has borrowed from the International Monetary Fund (IMF) and employed structural adjustment policies to guarantee access to IMF funding, whereas the first subset has not adopted such measures (Kregel, 2009). 


\subsection{A brief panorama of the external position of the countries}

The external position of China is totally different from the other countries'. Unlike Brazil, Russia, India and South Africa, the Chinese International Investment Position (IIP) ${ }^{7}$ is extremely favorable. In the case of China, this indicator is dominated by international assets belonging to the residents of the Chinese economy. Besides that, this economy has accumulated a large stockpile of foreign exchange reserves, which are the main components of the IIP. Foreign liabilities do add up to huge amounts, but they are mainly composed of FDI, which in China is destined to technology intensive sectors and is mainly comprised by long term capital. On the other hand, Russia is a distinct case among the BRICS countries with regard to its external position, as it neither presents the Chinese performance as measured by the IIP, nor the problematic stock of foreign assets and liabilities, as we will see below for the three remaining countries of the group.

Table 1 shows a positive Russian IIP during the first ten years of the millennium; however there were periods of negative balance, which meant an increase in the stock of foreign liabilities. Yet, the current account balance (CC) in relation to the gross domestic product (GDP) is favorable in the Russian economy, where at the beginning of the 2000 decade the CC surplus represented $10 \%$ of the GDP. Brazil, India and South Africa have shown different scenarios of recurrent deficits in current transactions during the last years.

Furthermore, the different external insertion of these three countries can also be observed by means of the IIP, which is extremely negative in these economies. It means that, despite their international reserves, these countries are receiving such strong foreign inflows that the external liabilities exceeded the asset reserves between 2000 and 2010. It can be said that the financial openness of these countries is very high in terms of capital flows towards their financial markets.

Thus, based on the similarities and differences in terms of external macroeconomic performance among the BRICS economies, we will separately examine the dynamics of financial flows towards these countries during the period 2000-2010, which includes the favorable period of the international liquidity cycles (between 2002 and 2007), the period of the international financial crisis as well as the subsequent recovery.

\footnotetext{
${ }^{7}$ The International Investment Position (IIP) shows the external assets and liabilities of the reporting country. The assets are broken down into five items: direct investment abroad, portfolio investment, financial derivatives, other investment and reserve assets; the liabilities are broken down into four items: direct investment in the reporting economy, portfolio investment, financial derivatives and other investment. It is a comprehensive way to measure the net external liabilities of an economy.
} 
Table 1 - BRICS and financial openness in terms of Current Account Balance and International Investment Position

\begin{tabular}{c|c|c|c|c|c|c|c|c|c|c}
\hline \multirow{2}{*}{ Year } & \multicolumn{2}{|c|}{ Brazil } & \multicolumn{2}{c|}{ China } & \multicolumn{2}{c|}{ India } & \multicolumn{2}{c}{ Russia } & \multicolumn{2}{c}{ South Africa } \\
\cline { 2 - 10 } & $\begin{array}{c}\text { CC } \\
\text { (\%GDP) }\end{array}$ & $\begin{array}{c}\text { PII } \\
\text { (net) }\end{array}$ & $\begin{array}{c}\text { CC } \\
\text { (\%GDP) }\end{array}$ & $\begin{array}{c}\text { PII } \\
\text { (net) }\end{array}$ & $\begin{array}{c}\text { CC } \\
\text { (\%GDP) }\end{array}$ & $\begin{array}{c}\text { PII } \\
\text { (net) }\end{array}$ & $\begin{array}{c}\text { CC } \\
\text { (\%GDP) }\end{array}$ & $\begin{array}{c}\text { PII } \\
\text { (net) }\end{array}$ & $\begin{array}{c}\text { CC } \\
\text { (\%GDP) }\end{array}$ & $\begin{array}{c}\text { PII } \\
\text { (net) }\end{array}$ \\
\hline $\mathbf{2 0 0 0}$ & $-3,77$ & n.a & 4,13 & 221.850 & $-0,96$ & -75.953 & 18,03 & 64.545 & $-0,12$ & -6.789 \\
\hline $\mathbf{2 0 0 1}$ & $-4,19$ & -264.966 & 5,87 & 265.221 & 0,28 & -70.018 & 11,06 & 43.911 & 0,28 & -11.061 \\
\hline $\mathbf{2 0 0 2}$ & $-1,52$ & -230.552 & 7,57 & 343.337 & 1,38 & -59.869 & 8,43 & 37.179 & 0,82 & -9.893 \\
\hline $\mathbf{2 0 0 3}$ & 0,75 & -272.555 & 10,38 & 394.159 & 1,48 & -46.241 & 8,22 & 3.924 & $-0,99$ & -12.094 \\
\hline $\mathbf{2 0 0 4}$ & 1,75 & -297.693 & 9,48 & 424.752 & 0,11 & -43.246 & 10,06 & -10.635 & $-3,03$ & -20.959 \\
\hline $\mathbf{2 0 0 5}$ & 1,57 & -316.593 & 11,35 & 439.360 & $-1,27$ & -47.436 & 11,05 & -31.567 & $-3,46$ & -33.955 \\
\hline $\mathbf{2 0 0 6}$ & 1,24 & -368.861 & 12,07 & 518.330 & $-1,02$ & -59.682 & 9,53 & -38.793 & $-5,3$ & -41.069 \\
\hline $\mathbf{2 0 0 7}$ & 0,11 & -547.548 & 12,33 & 483.700 & $-0,7$ & -74.766 & 5,92 & -150.600 & $-6,97$ & -68.380 \\
\hline $\mathbf{2 0 0 8}$ & $-1,7$ & -283.614 & 13,69 & 622.750 & $-1,98$ & -85.880 & 6,24 & 254.794 & $-7,11$ & -11.294 \\
\hline $\mathbf{2 0 0 9}$ & $-1,51$ & -600.795 & 8,58 & 720.060 & $-2,82$ & -122.901 & 4,05 & 103.431 & $-4,05$ & -40.208 \\
\hline $\mathbf{2 0 1 0}$ & $-2,26$ & -700.789 & 6,21 & 693.800 & $-2,62$ & $n . a$ & 4,8 & 15.680 & $-2,78$ & $n . a$ \\
\hline
\end{tabular}

Source: World Economic Outlook Database (IMF) and International Financial Statistics (IMF) - 2011

Notes: $\mathrm{CC}=$ Current Account Balance (\% of GDP); PII (Net) = International Investment Position (millions of dollars); the data of China correspond only to Hong Kong because of data availability.

\subsection{The dynamics of financial flows to the BRICS}

The aim of this section is to show that the BRICS economies present peculiar characteristics regarding financial dynamics. We will observe that the performance of each country's capital account follows the movement of the international liquidity cycles. The hypothesis underlying the analysis of the dynamics of financial flows to these countries is that external volatility and the implementation of macroeconomic policies depend on the effectiveness of the measures to manage financial flows. Thus, in order to reduce external vulnerability it is necessary to contain short-term financial flows. This vulnerability can be analyzed using Minsky's analysis of financial fragility. As proposed by Kregel (2004), countries that borrow in international financial markets to supplement the resources necessary for their development can be classified according to the different financing profiles presented in section 2 (Hedge position, Speculative position and Ponzi position). Developing countries have a high propensity to require shortterm funding associated with a speculative financing profile, which is highly likely to turn into a Ponzi financing profile. Therefore, free financial flows can exacerbate financial instability, in line with Minsky's framework.

It is not an objective of this paper to focus on detailed measures for managing capital controls, but it is important to discuss why capital controls are desirable. Controls or capital flow management may be needed in order to avoid reversion of financial flows - the famous sudden stop, among other reasons. Focusing on the effectiveness of capital controls, Magud and Reinhart (2006) argue that they may have the following benefits: 1) limit capital inflows, 2) change the composition of flows (especially towards long-term liabilities), 3) relieve pressures 
on the real exchange rate and 4) create greater autonomy for monetary policy through the proximity between the domestic and international interest rates.

According to Carvalho and Sicsú (2006), the theoretical argument often stressed to support the imposition of controls is the existence of externalities and the absence of perfect and complete markets that generate inefficient markets situations. In addition to this theoretical rationale, the authors mention reasons concerning the fundamental and radical uncertainty that surround transactions with financial and capital assets. Thus, the isolation of an economy in the face of external shocks and the autonomy for domestic economic policy would be the main goals to be achieved via the existence of capital controls.

Another important point regarding capital control is that there important changes in the ideas of academic economists and among IMF staff in such a way that a new institutional view $^{8}$ was endorsed by the IMF with respect to the regulation of capital inflows.

To achieve the empirical objectives, we will examine the dynamics of the financial flows directed towards this set of economies. The analysis will be based on the detailed examination of the financial accounts of the Balance of Payments of each country and their sub-accounts, focusing on the composition and profile of the financial flows. Moreover, we will use the Generalized Autoregressive Conditional Heteroskedasticity (GARCH) method to examine the volatility of the financial accounts in order to detect the times when there are peaks of volatile capitals, and to associate (or not) these peaks with the cycles of international liquidity.

It should be noted that these accounts will be examined in detail to allow the analysis of direct investment, portfolio investment, other investments and derivatives both in their asset and liability forms. We will refer to these sub-accounts as the first level of openness of the financial accounts and their asset and liabilities will be referred to as the second level of openness. The source of all the data used in the study is the International Financial Statistics database of the IMF.

For the use of GARCH modeling, many steps are necessary before the volatility of each series can be measured. The results of unit roots tests and of ARCH tests are presented in Tables I to $V$ of Annex 1 and in Tables VI to X of Annex 2, respectively. The series of data on capital flows utilized in the model are presented in Annex 3.

In the following section, each component will be examined in terms of the volatilities of financial flows.

\section{Brazil}

The GARCH model identifies a high volatility in the financial sub-accounts of Brazil's balance of payments during the period analyzed. Graph 2 shows that in the recent period (between 2000 and 2010) the highest volatility levels were seen in portfolio investment accounts and other accounts that aggregate short term flows. Even so, we can note a strong volatility in the direct investment account between 2007 and 2008 that requires qualification. This volatility was due to the big leap in foreign direct investments (FDI) that year. Indeed, total FDI made by transnational companies amounted to the record level of US\$1,8 trillion in 2007, representing a $30 \%$ increase in relation to the previous year according to UNCTAD (2008).

In the Brazilian case, the increase was even higher that year, reaching an $83 \%$ growth rate. In other words, in that year there was an upward shift in the FDI series. In 2008 the

\footnotetext{
${ }^{8}$ See IMF (2012b).
} 
inflows continued, but a reversal started in the fourth quarter of the year. This reversal continued during 2009, when there was a $42 \%$ decline in flows. However, in 2012, while developed countries received little FDI, developing countries once again strongly attracted direct investments. For the first time in history, they surpassed developed countries in terms of FDI attraction. Brazil, once more, received expressive inflows, with a yearly increase of $87 \%$ leading to another shift in the trajectory. It can be observed that the 2008 crisis brought about a reversal in FDI flows, but there was a rapid recovery of the trajectory of attraction.

Graph 2 - GARCH Volatilities for the series of the first level of openness of the Brazilian financial account $-\mathbf{2 0 0 0}$ to 2010

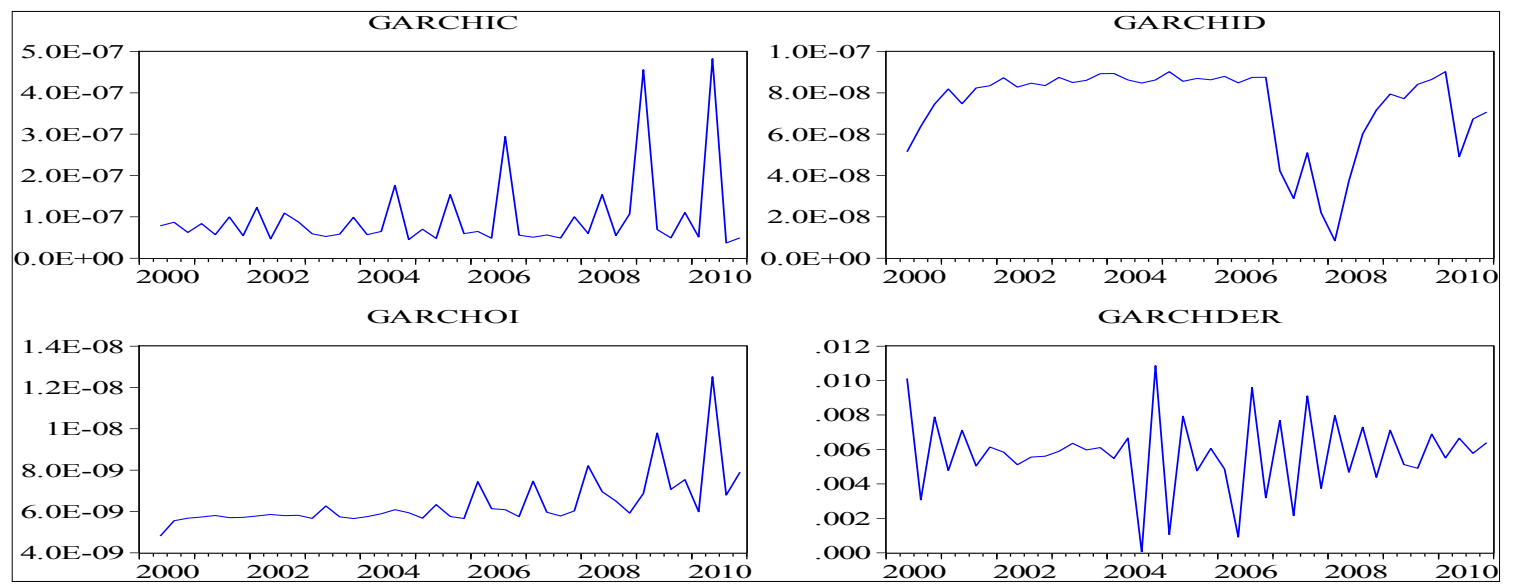

Source: Own elaboration from IMF data and using Eviews 7.0. Notes: GARCHIC = Portfolio Investment Variance; GARCHID = Direct Investment Variance; GARCHOI = Other Investment Variance; GARCHDER = Derivatives Variance.

When the financial account of Brazil's balance of payments is disaggregated by the second level of openness, the increase in volatility during the period under analysis becomes even clearer. Graph 3 shows that during the first half of the 2000 decade there was an uniform trajectory of the financial sub-accounts of the balance of payments while, mainly from 2007, such sub-accounts started to present a more irregular movement.

The strong outflow of Direct Investment Abroad during the fourth quarter of 2006 deserves attention. Such fact corresponds to the purchase of the Canadian Mining Company Inco by the company Vale do Rio Doce, after a process of growing internationalization of Brazilian companies, according to reports by the National Bank for Economic and Social Development, BNDES (2007).

\section{Graph 3 - The Financial Account of Brazil - second level of openness (US\$ million)}

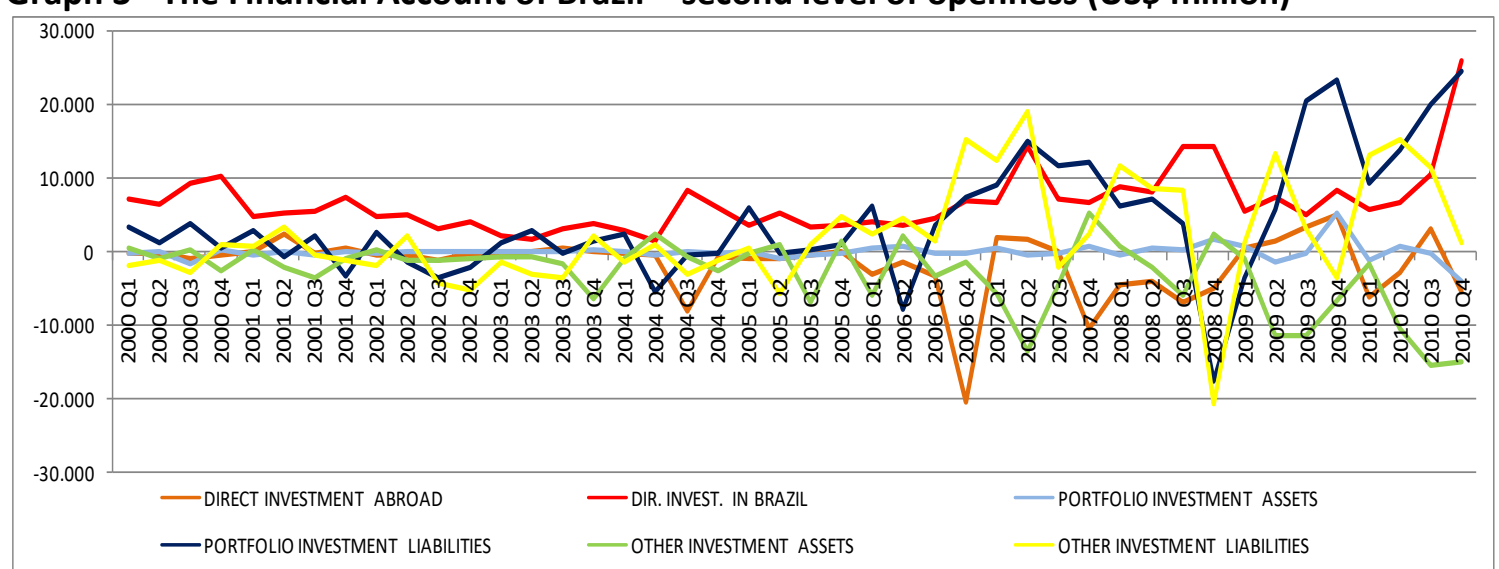

Source: IMF, International Financial Statistics. 
It must be noted that due to the rapid recovery from the subprime crisis that started in 2007, Brazil became more attractive to foreign capitals. This can be proved through the analysis of the direct investment (IDE) sub-account, which ends 2010 with approximately US\$ $25,000,000$. Besides the large IDE inflow, the country has strongly attracted short-term capital in the form of portfolio investments.

These capital inflows produced an appreciation of the domestic currency, and thus encouraged the taking of short-term positions in foreign currency. In this way, it caused economic units to become more reckless in the risks they undertake, and resort to greater speculative financing, in line with Minskyan perspective. The consequence is that Brazil became more speculative, endogenously, within the period under analysis.

Finally, we cannot forget to mention that, in the case of Brazil, much of the exchange rate appreciation seen in recent years - in 2010 only, the Real appreciated 30\% against the dollar - is associated with carry trade operations. Thus, the instrument used by the government, the IOF tax, has not achieved the desired efficiency, and should not, from the point of view of this paper, remain as the main strategy to control the speculation plaguing Brazilian financial account.

\section{Russia}

Observing the GARCH volatilities of the series for the first level of openness of the Russian financial account (Graph 4), we can clearly see that the peaks of volatility happened only more recently, as a result of the international financial crisis.

These peaks of volatility in the recent period may also be related to the fact that, lately, Russia has been liberalizing several financial transactions (Paula and Barcelos 2011). The differentiated unremunerated reserve requirements (URRs) were lifted in 2006. Capital flows reverted in 2008, especially in the other investment account. Therefore, inward and outward capital flows were facilitated, increasing the weight of speculative flows in this economy. This occurred because Russia is the most financially open in BRICS countries.

Graph 4 - GARCH Volatilities for the series of the first level of openness of the Russian financial account $-\mathbf{2 0 0 0}$ to 2010

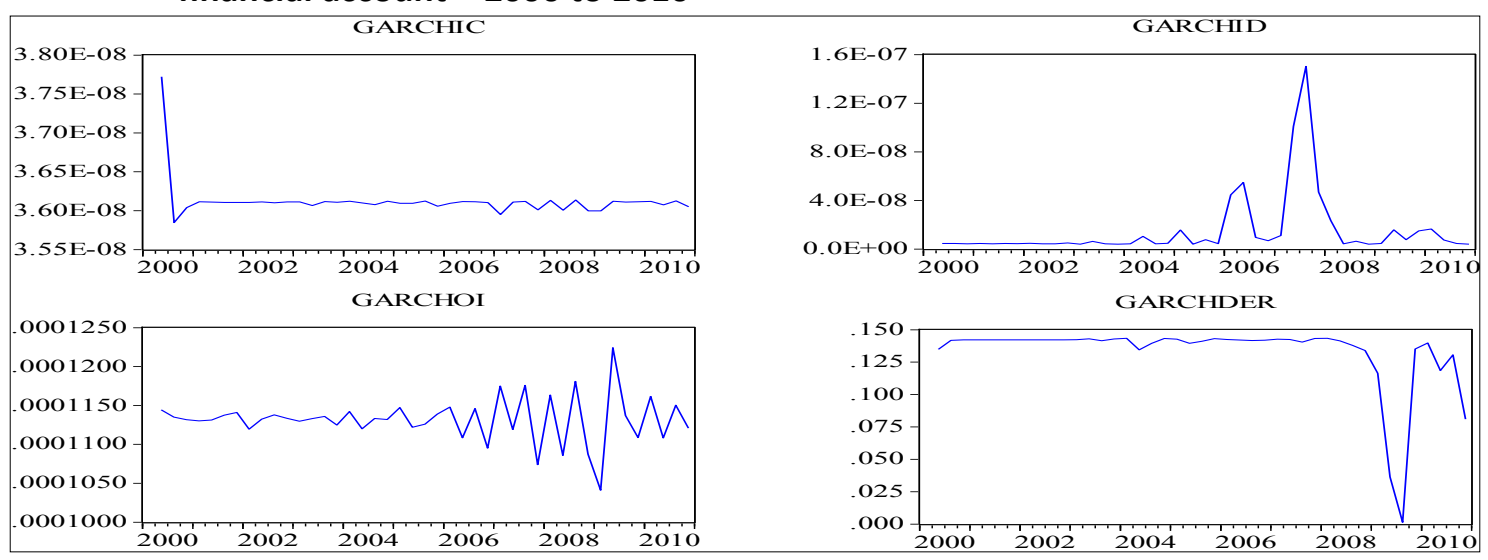

Source: Own elaboration from IMF data and using Eviews 7.0. Notes: GARCHIC = Portfolio Investment Variance; GARCHID = Direct Investment Variance; GARCHOI = Other Investment Variance; GARCHDER = Derivatives Variance.

Graph 5 presents the sub-accounts for the second level of openness of the Russian balance of payments. It can be noted that, during the second half of the 2000 decade, the financial sub-accounts showed greater volatility. Therefore, the oscillation of the Other 
Investments (asset and liabilities) sub-accounts becomes evident, indicating the short-term character of these flows. Moreover, these sub-accounts registered a much higher volume of financial resources when compared to the accounts of Brazil, India and South Africa. It must be emphasized that, like the other analyzed countries, Russia received a large inflow of capital through Direct Investment as from the mid-2007. Buoyed by ever increasing oil prices, gross private capital inflows increased from around $\$ 70$ billion in 2005 to $\$ 100$ billion in 2006 to over $\$ 200$ billion in 2007, especially in terms of other investments and direct investment. These huge inflows have affected the volatility of these sub-accounts.

Due to the international financial crisis, other investments reversed in such a way that the total financial account reached $8 \%$ of GDP in the fourth quarter of 2008. Portfolio flows also reacted to the crisis. However, this cannot be seen on Graph 4 (which shows the GARCH volatilities) due to a strong variation in these flows at the beginning of the period under analysis, which distorted the values for the volatility in the subsequent years. This massive capital flight in 2008-2009 led to a significant devaluation of the ruble between 2008 and January 2009. However, the domestic authorities did not resort to capital controls in those years.

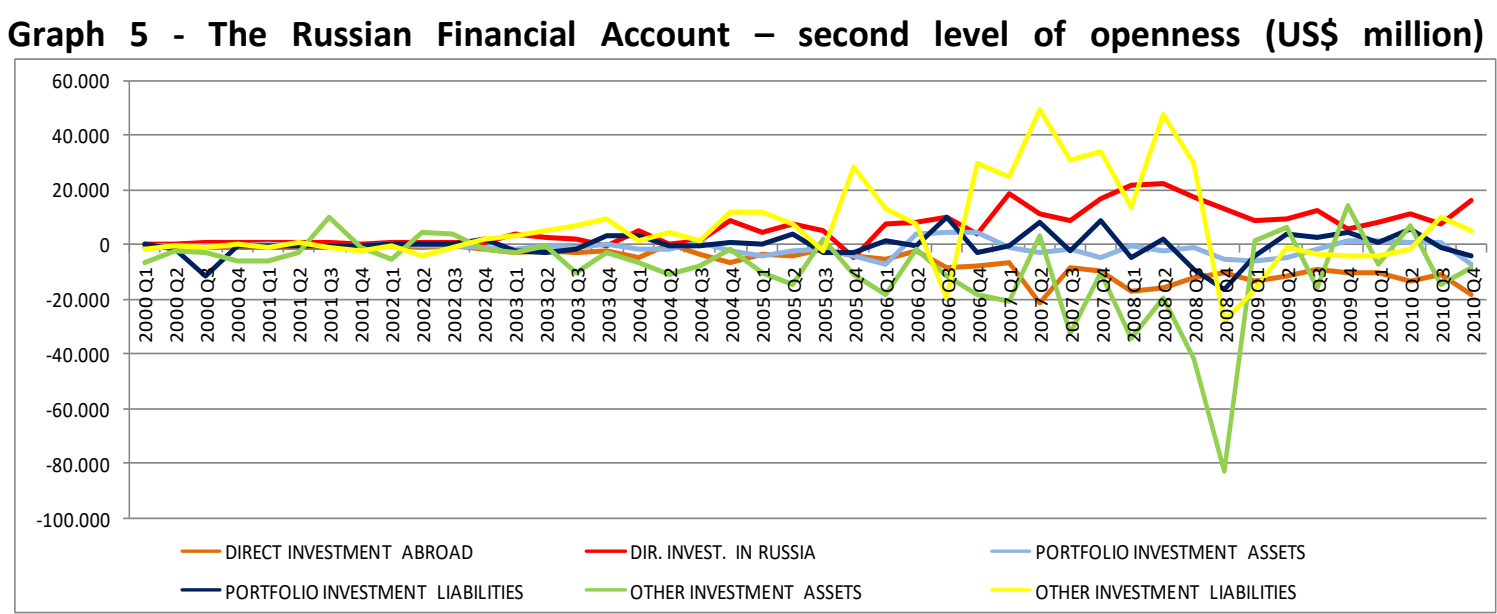

Source: IMF, International Financial Statistics.

Thus, we believe that the capital controls introduced by Russia are successful examples of restrictions on capital outflows, especially when we consider this economy's rapid recovery in terms of attracting capital flows in recent years. Among emerging countries, a report by the IIF (2011) shows that Russia and Turkey were the countries that saw increases in capital flows. "In Russia, the rebound in private inflows was due mainly to the cessation of net repayments to foreign banks" (IIF, 2011, p.16). Analyzing the Russia case from a Minskyan point of view we can state that the capital control regulation made the country less fragile from the external perspective.

India

The capital flows towards India do not suffer volatility peaks as in the case of the other BRICS countries. Among the quantitative capital controls, there is a prevalence of controls on outflows. We can observe in Graph 6 that it was only in the recent period, at the height of the financial crisis of 2008, that the GARCH volatilities displayed peaks. In response to the international financial crisis, the amount of short-term bonds that could be sold to foreign investors was limited (while the overall ceiling for Fll investment in debt was raised in September 2011). Hence, the sub-accounts Portfolio Investment, Direct Investment and Other Investments only show high peaks of volatility in the recent period. 
Such fact indicates the distinct dynamics of the financial flows directed to emerging economies, which follow the flows of international liquidity. At times of slow global growth and international liquidity shortage, as during the height of the financial crisis of 2008 , there is a significant flight of these capitals from emerging economies.

The analysis of the second level of openness of the India's financial account (Graph 7) shows a marked volatility in financial flows from 2006 onwards and a change in the volume of inward resources. The first half of the decade presented lower average volumes of capital inflows than the second, which means that the economy only started to receive larger amounts of financial resources during the recent global liquidity cycle.

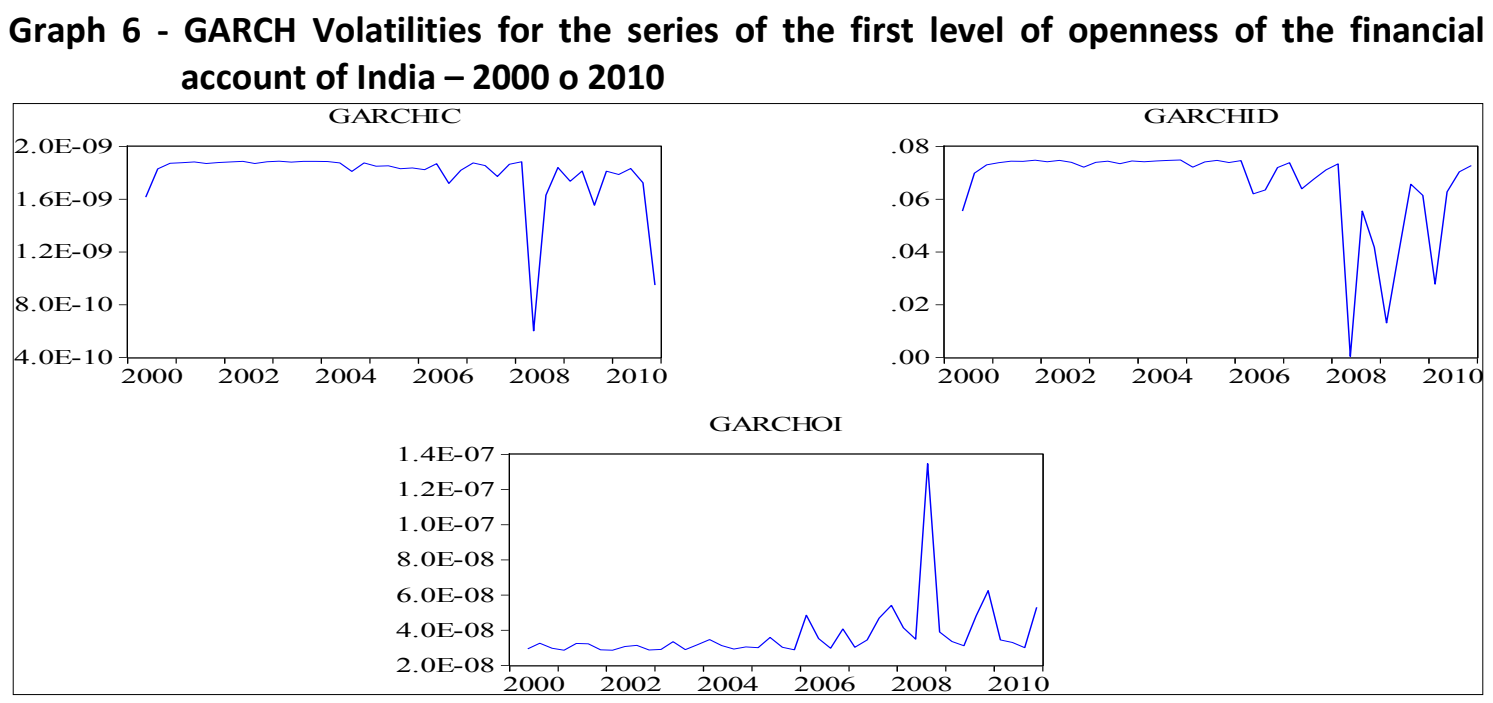

Source: Own elaboration from IMF data and using Eviews 7.0. Notes: GARCHIC = Portfolio Investment Variance; GARCHID = Direct Investment Variance; GARCHOI = Other Investment Variance.

The sub-accounts that showed the least stability were other investments and portfolio investments, which are characterized by short-term transactions. Regarding the attraction of capitals via FDI, India follows the tendency of the other countries under study, receiving large inflows as from 2006. The FDI sub-account presents greater instability than the others.

\section{Graph 7: Financial Account of India - second level of openness (US\$ million)}

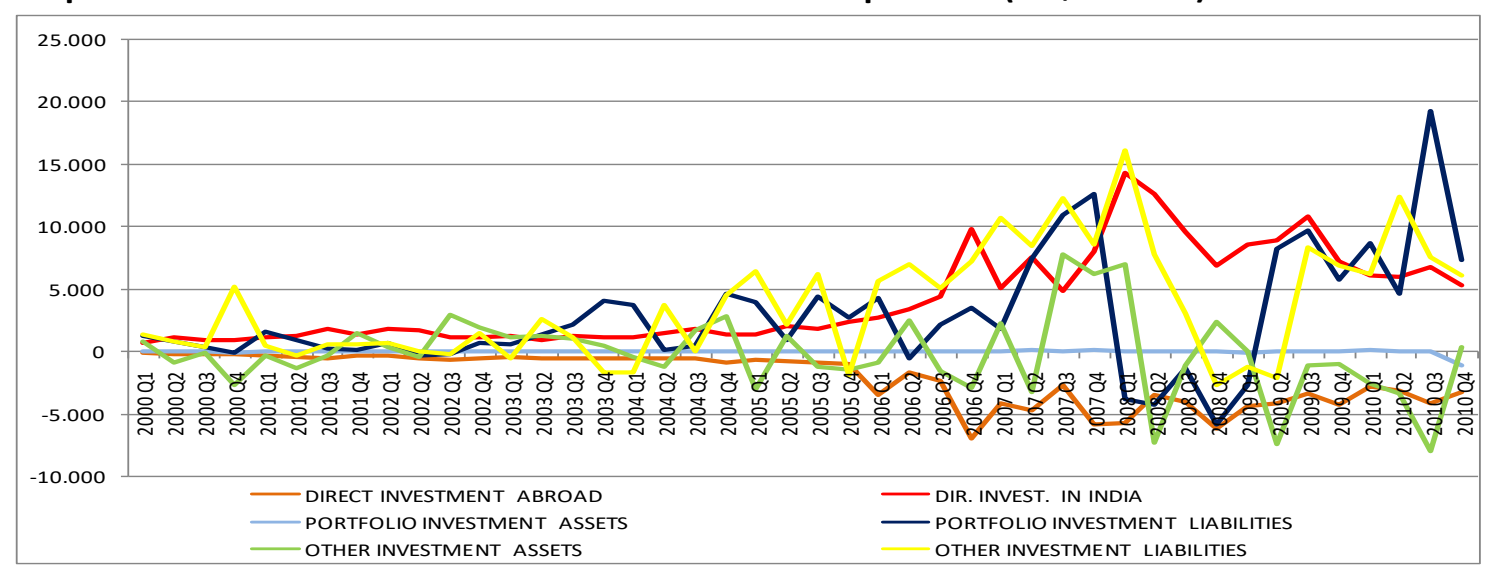

Source: IMF, International Financial Statistics.

As a result, we can say that, in general, the Indian authorities combine greater reliance on non-investment inflows (FDI) with greater flexibility of the exchange rate, which can be seen by the strong appreciation of the Rupee in recent years. This increase in the value of domestic currency is cause for some concern, leading to government interventions in the currency market, as was the case in 2010. But the strategy of accumulation of international 
reserves and the use of capital controls play an important role in the country, as is evident from the control measures outlined above. The tolerable increase in the current account deficit, from 2005 onwards (see Table 1), led the government to raise the limits on foreign commercial loans for purposes of investment in infrastructure and a minimum maturity of five years.

India has less difficulty controlling capital inflows due to comprehensive strategies to manage the potentially destabilizing capital flows. So, the country's external position is less speculative from a Minskyan perspective.

\section{China}

China has an extensive and lasting experience with the use of controls on international capital flows. Because of the capital controls adopted, long-term inflows (especially FDI) are favored over short-term inflows. We observe on China's financial account a high share of FDI inflows and a lower participation of portfolio investment liabilities over the period 2000-2010. In addition, FDI reaches much larger volumes compared to the other BRICS countries. It is believed that this was achieved through requirements stipulated in administrative measures and quantitative restrictions on capital flows.

The measures of capital controls in China aimed at preventing illegal capital outflows and maintaining a stable exchange rate. While the measures have reduced illegal activities, there were widespread reports, according to Ariyoshi et al (2000), that legitimate transactions have also been adversely affected. Moreover, Zhang (2011) point out that China's capital controls strategy has a counter-cyclical style, which demonstrates the government's effort to avoid vast capital outflow or inflows.

The analysis of the GARCH model for China clearly shows these effects of crisis on this economy (Graph 8). Financial volatility increased in the sub-accounts Portfolio Investment and Other Investments, which are composed of flows of a more speculative nature. In the case of the Direct Investment account, it can be noted that the highest peak of volatility did not occur during the height of the 2008 financial crisis, but in mid-2004. The Derivatives sub-account, which represents a small share of the Chinese financial account, showed a more regular trajectory, with volatility peaks happening only at the beginning of the decade.

Graph 8 - GARCH Volatilities for the series of the first level of openness of the Chinese Financial Account - 2000 to 2010

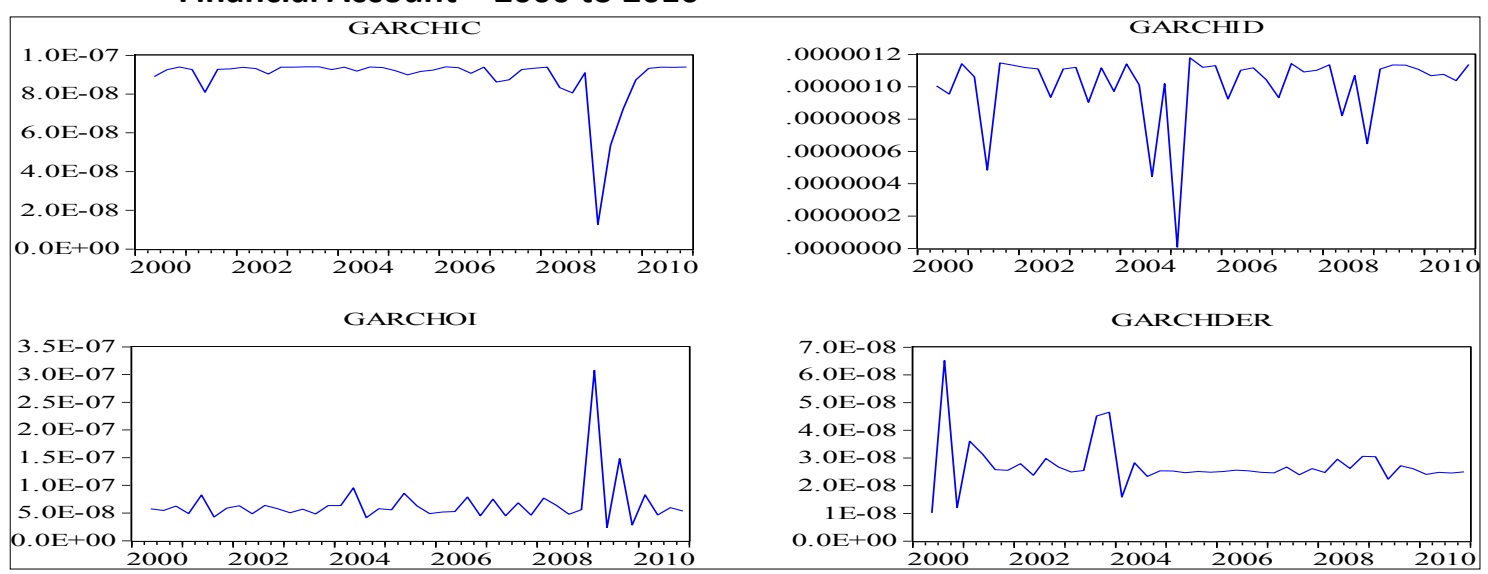

Source: Own elaboration from IMF data and using Eviews 7.0. Notes: GARCHIC = Portfolio Investment Variance; GARCHID = Direct Investment Variance; GARCHOI = Other Investment Variance; GARCHDER = Derivatives Variance. 
The analysis of the second level of openness of the Chinese financial account during the 2000 decade (Graph 9) shows great volatility of financial flows, mainly from 2007 . The subaccounts that best represent this instability are Other Investments (asset and liabilities), which comprise short-term transactions. The behavior of this sub-account resembles that of Russia, another large recipient of financial flows - as seen on the graphs for the financial accounts, which show high values for both countries.

Once again, it should be mentioned that during most part of the analyzed period China has presented itself as an attractive country for Direct Investment. For this country, the Portfolio Investment sub-account does not show strong levels of volatility, except for the capital flight experienced at the height of the 2008 financial crisis, showing the effectiveness of the Chinese capital controls.

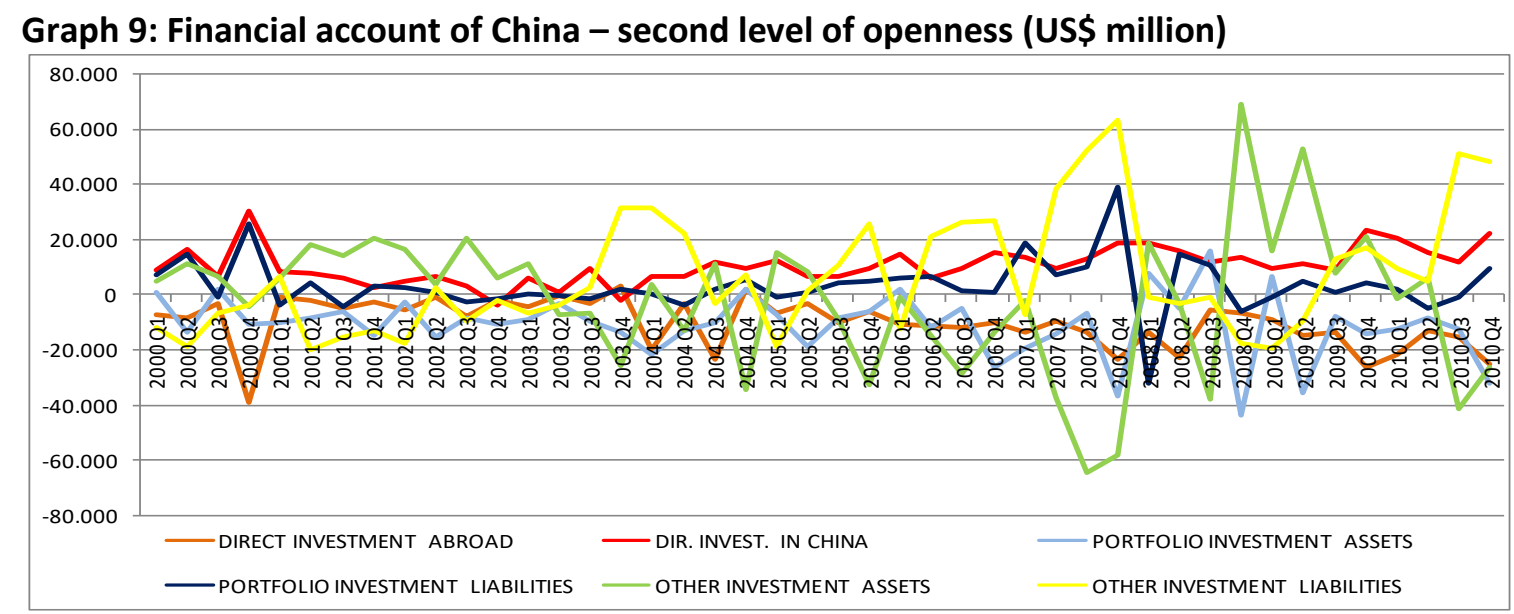

Source: IMF, International Financial Statistics.

Thus, our analysis is consistent with Bibow's (2011), for whom China's regime for the management of capital flows can be considered a model for other BRICS countries, especially because of portfolio investment and short-term debt $^{9}$ are still regulated tightly through quantitative measures.

\section{South Africa}

On examining the GARCH volatilities, through Graph 10, it can be observed that the flows of the first level of openness of the South African financial account presented instability during the entire period under analysis. In 2001, when the country suffered a monetary crisis, outward capital flows in the form of Portfolio Investment brought about a significant peak of volatility. More recently, as a result of the international financial crisis, capital reversals of the same type have also led to expressive peaks.

However, according to Habermeier, Kokayne and Bamba (2011), the country adopted prudential measures to curb the asset price boom and the currency appreciation. Domestic lending rules were tightened in June 2007. In addition, rules on haircuts applied to eligible collateral were introduced, and banks were made subject to an additional capital charge to take into account concentration risk and interconnectedness in 2008. Long-term insurers' policy underwriting business was increased to 20 percent, and the investment-linked business

\footnotetext{
${ }^{9}$ Portfolio investment is controlled by quotas and short-term debt is subject to a ceiling. More specifically, Portfolio investments are under the Qualified Foreign Institutional Investors scheme (QFII) for inflows and Qualified Domestic Institutional Investors scheme (QDII) for outflows, respectively. External borrowing by eligible entities remains subject to quotas.
} 
was set at 30 percent of total retail assets under management in 2008. In March 2010, South African banks were allowed to acquire direct and indirect foreign exposure up to $25 \%$ of their total liabilities.

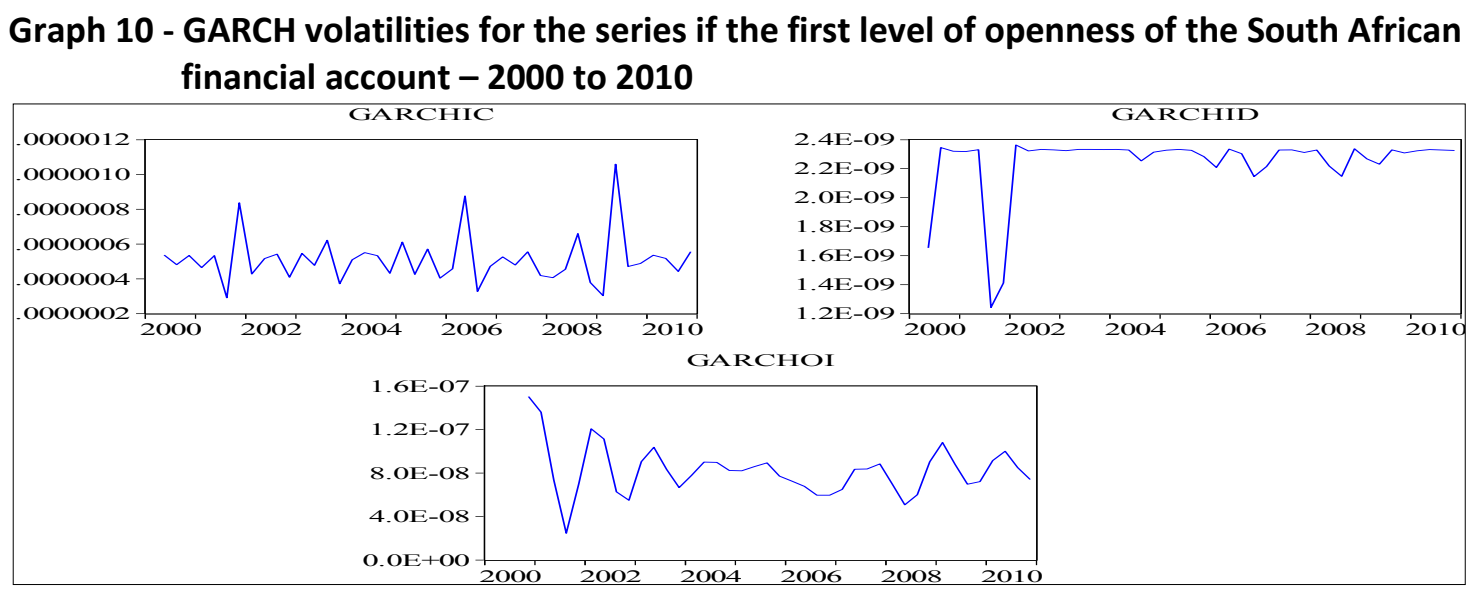

Source: Own elaboration from IMF data and using Eviews 7.0. Notes: GARCHIC = Portfolio Investment Variance; GARCHID = Direct Investment Variance; GARCHOI = Other Investment Variance.

The analysis of the second level of openness of the South African financial account (Graph 11) indicates some volatility in the sub-accounts examined at the beginning of the 2000 decade, which gains strength in the second half of the decade. It is worth highlighting the volatility peaks in 2001, when the country faced a monetary crisis.

The sub-accounts that show the greatest instability, with the most inflow and outflow peaks during the whole period, are Portfolio Investment (liability), Other Investments (asset) and Direct Investment in South Africa. Regarding the last sub-account, it can be noted that the country received capitals even during the financial crisis that started in 2007, with a small decline in these inflows in 2010. At the height of the crisis, during the fourth quarter of 2008, the sub-account that suffered the largest impact was Portfolio Investment, precisely the one with a speculative profile. This shows the vulnerability of the South African economy in the face of external events. Moreover, it can be noted, through Graphs 10 and 11, that this subaccount easily recovers during the post-crisis period, which shows that South Africa is one of the emerging economies that has strongly attracted foreign investors.

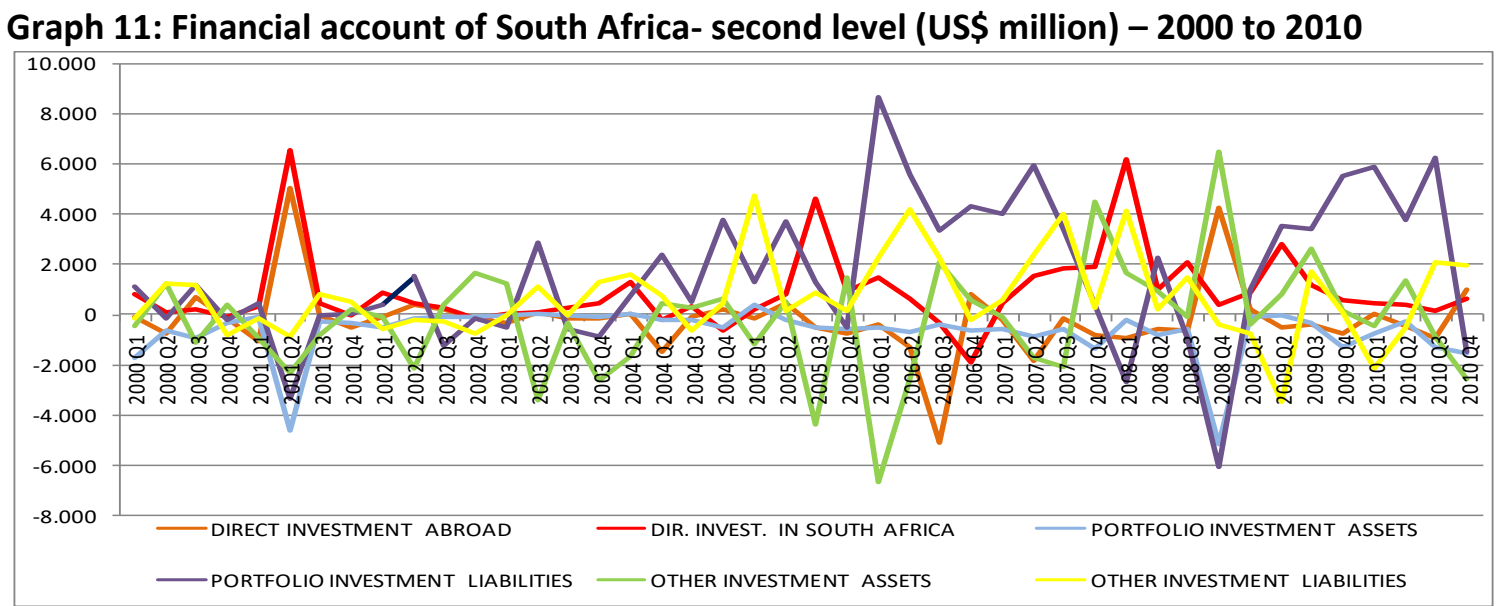

Source: IMF, International Financial Statistics.

However, according to the IMF (2011), the possibility of controls on inflows permanently expelling capital flows is a concern of both domestic authorities and market participants. Thus, we once more stress that the absence of comprehensive capital controls, as 
was observed for the Brazilian case, can lead BRICS countries and other emerging economies to increasingly unfavorable situations. For Mohamed (2006), the surges have not contributed to investment in productive capacity that will lead to future growth in the economy.

\subsection{Capital account regulation in BRICS}

\subsubsection{The defense of restrictions on (unfettered) capital flows}

There is a vast literature analyzing the negative impact of a capital account operating freely across borders, even among the various theoretical approaches. Although the proliberalization bias remains, the IMF and authors typically from the orthodox field had begun to "flirt", indirectly and partially, with the Chilean-type of capital controls (on capital inflows). In fact, the Fund generally admits that limited and temporary controls deserve further study and attention.

Generally, controls or capital flows management may be needed in order to avoid reversion of financial flows - the famous sudden stop. For Magud and Reinhart (2006) capital controls are imposed on four basic fears: fear of appreciation, fear of hot money, fear of large inflows, and fear of loss of monetary autonomy ${ }^{10}$.

Through an analysis of 30 empirical studies on this topic and constructing two indicators of capital controls, Magud and Reinhart (2006) found the following results: the area where capital controls have greater success is in providing greater autonomy to monetary policy and changing the composition of capital inflows, while success in reducing the volume of inflows and the pressure in exchange rate had mixed result.

Capital controls have been found to stabilize short-term volatile capital flows; and can give policymakers additional policy instruments that allow them more effective and less costly macroeconomic stabilization measures; can promote growth and increase economic efficiency by reducing the volatility of financing and of real macroeconomic performance; and can discourage long-term capital outflows (Ostry et al., 2010).

Another point frequently and sometimes more intensely addressed by advocates of controls is the relationship between capital movements and exchange rates. The free movement of capital increases exchange rate volatility under floating exchange rates. During a crisis, herd behavior can cause an exchange rate overshooting. The sudden reversal of capital flows results in large depreciation of the nominal exchange rate, which tends to increase financial problems of domestic borrowers and to generate inflationary pressures. Thus, exchange rates can reach excessive levels in times of crisis, as it was the case in Brazil in 2002, deteriorating market expectations.

Grabel (2003) argues that "regulation of IPCFs is a central component of what can be thought of as a 'developmentalist financial architecture', by which I mean a financial system that promotes equitable, stable and sustainable economic development". (Grabel, 2003, p. 342).

Other arguments also raised by the advocates of restrictions on capital flows suggest the possibility to tax the capital income, enabling the adoption of distributive tax policy - when preventing domestic agents to transfer resources to countries with lower taxes; and the possibility of being used as instruments of industrial policy to shape the structure of domestic supply - when encouraging inflows of foreign direct investment in specific sectors.

${ }^{10}$ Ocampo and Palma (2008) add a fifth fear to justify the capital controls: the fear of asset bubble. 
Epstein, Grabel and Jomo (2005, p. 6) propose capital management techniques (henceforth CMTS) "to refer to two types of complementary financial policies: policies that govern international private capital flows, called 'capital controls', and those that enforce prudential management of domestic financial institutions". From these, the authors suggest seven lessons listed below: i) CMTS can promote financial and monetary stability, macro and microeconomic autonomy policy, stable long-term investment and sound current account performance; ii) the successful implementation of controls over a significant period of time depends on the presence of a sound policy environment and strong fundamentals (relative low debt ratio, moderate rates of inflation, sustainable fiscal balances and current account, consistent exchange rate policies), iii) there is synergy between CMTS and economic fundamentals, iv) nimble and flexible capital is very desirable; v) CMTS work better when they are coherent and consistent with the overall aims of the economic policy regime coherent and consistent with overall purposes of the economic policy regime, or better yet, when they are an integral part of a national economic vision; vi) prudent regulations are generally an important complement to capital controls and vice versa; and vii) there is not a type of CMT that works better for all countries, once there are a variety of strategies.

Gallagher (2011) examine the role that capital flows have played in the global financial crisis, trace the political economy of capital controls from the Bretton Woods era to their resurgence during the financial crisis, and conduct a preliminary analysis to evaluate the effectiveness of the controls thus far deployed. The author points to the need for more concerted global and national efforts to manage global capital flows for stability and growth.

In spite of the importance of the policies of control of capital raised here, we will concentrate in the relation between capital controls and the stabilization of short-term volatile capital flows in BRICS.

\subsubsection{Some capital control measures adopted by the BRICS}

In Brazil capital controls have been adopted since 2008. In order to counter large capital inflows after the global crisis, the Brazilian government imposed a temporary tax on inflows of short-term capital (IOF - Imposto sobre operações financeiras), as a response to the massive upswing in inflows in 2009. The IOF tax on the entry of foreign funds and prudential measures are also adopted. Over the following two years, Brazil adopted a series of other measures to discourage inflows ${ }^{11}$, starting gradually to dismantle them in 2012. Following the main results of the capital flows volatility study, in section 3.2, the IOF was unable to contain the volume of speculative flows. Portfolio investments and other investment are the most volatile subaccounts between 2000-2010.

Russia started its financial liberalization process in the early 1990s, while reforming its banking system and foreign exchange and securities markets. After relaxing restrictions on portfolio investments by non-residents, Russia experienced increasing foreign exchange market pressures. As a consequence, in 1998, a series of emergency measures was introduced, including a reintensification of capital controls and the announcement of a selective debt moratorium (Ariyoshi et al., 2000). However, capital controls implemented after the 1998

\footnotetext{
11 October 2010: (i) IOF increased from 2\% to $4 \%$ for fixed income investments and equity funds. (ii) IOF increased to $6 \%$ for fixed income investments (iii) Limitations were also introduced on the ability of foreign investors to shift investment from equity to fixed income investment (iv) IOF on margin requirements on derivatives transactions increased from $0.38 \%$ to $6 \%$ (v) Some loopholes for IOF on margin requirements were closed.
} 
crisis $^{12}$, despite being comprehensive, were not fully effective. The capital account was reliberalized during 2004-06. Heavy capital inflows culminate in a sudden stop during 2008-09 due to international financial crisis.

Russia also imposed unremunerated reserve requirements (URR) on specific transactions, as well as Colombia and Chile, between 2004 and 2006 . Specifically, differentiated URRs were adopted from August 2004 to July 2006, and focused on $20 \%$ of nonresidents' investment reserves in government securities and $3 \%$ on non-residents' Other Portfolio investments and lending to residents. Thus, it highlights the importance of the latest controls adopted in Russia. Other investments (asset and liabilities) are the most volatile subaccounts, and registered much larger volumes when compared to the accounts of Brazil, India and South Africa.

Prior to the balance of payments crisis, that India suffered in 1991, official and private debt inflows were the main sources of external finance. Since this crisis, India has blocked debt inflows, especially short-term ones. By contrast, India has gradually opened up to equity inflows, both FDI and Portfolio investments. Portfolio inflows are managed through a "Foreign Institutional Investment" framework that requires registry of eligible foreign investors (Bibow, 2011). Thus, according Shah and Patnaik (2005), Indian capital controls consist of an intricate web of a large number of quantitative restrictions, operated by a substantial bureaucratic apparatus.

An important element of capital controls in India consists in barriers to arbitrage on the currency forward market through the banking regulation. The prudential regulation and supervision of the banking system strengthened in accordance with international standards. The regulation of the securities market has been modernized, the government's reliance on financing from the central bank was broken and the monetary authority made greater use of indirect monetary policy instruments. The central bank controls the interest rate that banks lend to foreigners through the deposits of non-residents. It is also used a broad set of tools to influence conditions in the foreign exchange market by interventions in the spot market, using future transactions and foreign exchange swaps, and accumulating foreign reserves. The cash reserve ratio was gradually increased from January 2004 through November 2007 as an important strategy of accumulation of international reserves and capital controls. As a result, the level of foreign exchange reserves rose from $\$ 32.4$ billion in 1998 to US $\$ 75.4$ billion in 2002, according to IMF data.

Portfolio Investment, Direct Investment and Other Investments show high peaks of volatility only in the recent period, since 2008. So, the capital flows towards India do not suffer volatility peaks as in the case of the other BRICS countries. Among the quantitative capital controls, there is a prevalence of controls on outflows.

In China, capital controls involve a detail of rules, managed by a complex of net of institutions and supervision of private decisions, which are oriented to minimize dependence on short-term funds. The aim, in this case, is to encourage the long-term inflow, particularly the foreign direct investment, what can be effective due to the amount of international reserves accumulated over the 1990s in this country. Ma and McCauley (2008) indicate that, in light of tight controls, Chinese authorities retain some degree of short-term monetary autonomy, despite the regime of fixed exchange rate to July 2005.Capital Account management through reserve requirements in China can be considered a model for other countries of BRICS. Some important measures were: September 2003 - December 2008: Raising reserve requirements 20 times; and eased restrictions on foreign banks' investments in yuan-

12 In particular, IMF (2012a) refers to the trading of short-term treasury bills that was suspended, the maturity of domestic debt compulsorily lengthened, and transfers abroad by non-residents restricted. 
denominated Chinese bonds held offshore. As a consequence, there is no strong volatility of Portfolio Investment, except for the capital flight at the height of the financial crisis in 2008. The highest volatility peak of Direct investments (the largest volume when compared to others countries of BRICS) did not occur during the height of the financial crisis in 2008, but in mid2004.

South Africa is a country that implemented an important liberalization of capital outflows. In 2001, the limit for foreign investments made by institutional investors was increased to 15 percent of all assets and foreign currency transfers were allowed up to 10 percent of the net inflow of funds. The limit for foreign investments was gradually increased in 2008. It also became significantly easier for South African residents to withdraw capital from the economy. Free movement of capital into and out of the economy is allowed for nonresidents. According to Mohamed (2006, p.2), "the government hopes that a large share of the capital required for domestic investment, employment creation and development of the economy will come from foreigners".

Within this approach, government policies on capital controls do not differentiate FDI and long-term flows of short-term capital flows. So, the lesson of the increase in capital inflows of the early 1990s and of the 2001 currency crisis is that uncontrolled capital flows have been very damaging to the South African economy. As a consequence, the exchange rate appreciated in late 2001, when the portfolio investments fled from the country and the Rand fell $35 \%$ against the dollar. More recently the country suffered strong appreciation of the exchange rate at the height of the financial crisis in 2008. In addition, the African country suffers from deficits in current account, like Brazil, which enhances the problem faced.

The results of the Capital flows volatility study show a huge impact on Portfolio Investment at the height of the financial crisis in 2008 and volatility peaks of Portfolio Investment (liability), Other Investments (asset) and Direct Investment between 2000 and 2010.

The empirical findings connected to the capital account regulations of each country analyzed suggest that the lower volatility of financial flows can be associated with the adoption of different strategies to manage capital flows. The extended Minskian perspective suggest that financial fragility is increased by the ability of investors to cross national borders and by the ability to foreign investments in domestic markets. So, we can conclude that opening up countries to foreign capital or countries less regulated in terms of capital accounts has likely led to increased financial crises and external vulnerability.

In other words, different policies in the different countries analyzed affected them differently, making Brazil and South Africa more fragile from the external perspective. These countries became more endogenously speculative in comparison to Russia, China and India within the period under analysis.

\section{Final Remarks}

After the financial deregulation and external liberalization processes that the BRICS countries started in the 1990s, there has been a surge of international capital flows towards these countries and the dynamics of such flows have been extremely unstable. This study showed that, if the weight of short-term capital flows in the balance of payments increases, dependence on external events grows. In fact, we noticed that potentially volatile capital flows are strongly influenced by current factors, mainly linked to the international financial crisis. The key moments of strong inflows follow closely the dynamics of international liquidity. 
In this way, this paper showed that such behavior deepened during the international financial crisis of 2007-2008. The empirical analysis showed that a significant reversal of capital flows was observed in all countries studied. But the analysis also demonstrated that this impact and the capital flows volatility are lower in countries that adopted capital controls. Thus, our hypothesis is corroborated: capital controls can help the economy to protect against destabilizing aspects of capital flows.

In Brazil, important measures were adopted in times of strong inflows, like the increase in the IOF tax on foreign capital and the tax on currency derivative operations. However, we can say that these measures were not sufficient given the challenges facing the economy. In turn, in Russia the need for permission from the central bank to make portfolio investments abroad and the requirement that the Russian credit institutions must have reserves for transactions with non-residents, as well as the implementation of URRs, were essential to protect the economy from the most severe impacts of the international crisis.

India, like China, is characterized by extensive and lasting capital controls. Thus, these economies present lower peaks of capital inflows and outflows. Following Paula and Barcelos' (2011) conclusions, we find that these countries adopted effective policies for the reduction of external vulnerability. However, India's potential for external vulnerability has increased in recent years due to financial liberalization and tolerance with recurring current account deficits. Recently, restrictions on capital outflows have been relaxed to allow increased investments abroad from both individuals and national companies. Thus, we see that the Indian economy has received strong inflows of capital of a short-term nature. The Chinese case is the most peculiar among the BRICS, since the country adopts a very unique development strategy and has an extremely favorable external insertion. We believe that the Chinese strategy to manage capital flows is effective and strongly contributes to the country's resilience to external events such as the global financial crisis, being a model for other BRICS countries.

Finally, South Africa is, like Brazil, an important destination for the surges of volatile capital flows. The country does not adopt more comprehensive capital controls, which increases the potential for external vulnerability. As a consequence, there are negative impacts on exchange rate volatility. At the height of the crisis, the South African economy suffered the second largest exchange rate appreciation among the BRICS. It is believed, therefore, that more extensive measures are necessary in this economy. Moreover, the country should aim at attracting long-term financial flows, able to contribute to output growth.

It must be noted that, as a result of inadequate restrictions on inward and outward financial flows, these economies are having to deal with progressively less freedom to conduct their economic policies. Moreover, they are also facing problems such as instability and financial vulnerability, as pointed out by Minsky (1986), because it is difficult for them to escape from the trap of a Ponzi financing profile and from the necessity of financial capital.

Therefore, we believe that financial market regulations must be dynamic and comprehensive, and that it is necessary to choose the appropriate types of capital controls, the ones most adequate for each circumstance and country. To accomplish this, it is essential to analyze the profile of new inward flows. Finally, we also believe that not only emerging countries should adopt capital control measures, but that developed countries should support the implementation of these measures by the capital recipient economies. For instance, local banks should play no role in facilitating the entry of speculative short-term flows. Mitchell (2010) presents some important strategies for banks in this process:

"First, they should only be permitted to lend directly to borrowers. All loans would have to be shown and kept on their balance sheets. (...) Second, banks should not be allowed to 
accept any financial asset as collateral to support loans. The collateral should be the estimated value of the income stream on the asset for which the loan is being advanced. This will force banks to appraise the credit risk more fully. Third, banks should be prevented from having "off-balance sheet" assets, such as finance company arms which can evade regulation. Fourth, banks should never be allowed to trade in credit default insurance. This is related to whom should price risk. Fifth, banks should be restricted to the facilitation of loans and not engage in any other commercial activity".

In sum, the capital control policy should be introduced on a multi-lateral basis spanning all nations.

\section{References}

Akyüz, Y. (1998). "The east asian financial crisis: back to the future?" Ginevra: UNCTAD. (Working Papers, 10). Available in: http://www.tni.org/detail_page.phtml?page=asemwatch_asem 25 .

Akyuz, Y. (2011). "Capital flows to developing countries in a historical perspective: will the current boom end with a bust and how?", South Center Paper, March.

Arestis , P.; Glickman, M. (2002). "Financial crisis in southeast Asia: dispelling illusion the minskyan way". Cambridge Journal of Economics, London, v. 26, n. 2, p. 237-260.

Ariyoshi, A. et al. (2000). "Capital controls: country experiences with their use and Liberalization". IMF Occasional Paper, n. 190.

Bibow, J. (2011). "Permanent and selective capital account management regimes as an alternative to self-insurance strategies in emerging market economies", Levy Economics Institute Working Paper, no. 683, September.

Brics Policy Center. (2011). Relatório da Cúpula de Sanya. BRICS Policy Center / Centro de Estudos e Pesquisa BRICS, august.

Carvalho, F. C.; Sicsú J. (2006). "Controvérsias recentes sobre controles de capitais". In: Câmbio e controles de capitais: Avaliando a eficiência de modelos macroeconômicos. SICSÚ, J.; FERRARI FILHO, F. Rio de Janeiro; Elsevier.

Dymski,G. A. (1999). "Asset Bubbles in the Korean and Japanese Crisis: A SpatializedMinsky Approach", Journal of Regional Studies,

Epstein, G. A.; Grabel, I.; Jomo, S. K. (2005). "Capital Management techniques in developing countries". In: Epstein, G. A. Capital flight and capital controls in developing countries. Cheltenham, UK: Edward Elgar.

Foley, D. K. (2003). "Financial fragility in developing economies". In: DUTT, A.K.; ROS, J. (Orgs.). Development economics and structuralist macroeconomics. Aldershot: Edward Elgar. p.157-168.

Forbes, K. (2007). "One Cost of the Chilean Capital Controls: Increased Financial Constraints for Smaller Traded Firms." Journal of International Economics, 71(2), 294-323.

Forbes, K. (2007). "Capital Controls".The New Palgrave Dictionary of Economics, $2^{\text {nd }}$ Edition, Forthcoming. Available at: http://web.mit.edu/kjforbes/www/Papers/Capita_ControlsPalgrave_Entry-Forbes.pdf. Accessed: 12 august 2013.

Fritz, B.; Prates, D.; Paula, L. F. R. (2014). "Keynes at the Periphery: Currency hierarchy and challenges for economic policy in emerging economies". In: Inequality and the Future of Capitalism, Berlim. Inequality and the Future of Capitalism, 2014. 
Gallagher, K. P. (2011). "Regaining Control: Capital Controls and the Global Financial Crisis." PERI working papers $\mathrm{n}=250$. University of Massachusetts-Amherst.

Grabel, I. (2003). "Averting crisis? Assessing measures to manage financial integration in emerging economies". Cambridge Journal of Economics, London, v. 27, n. 3, p.317-336.

IIF Research Note. (2011). "Capital Flows to Emerging Market Economies". The Institute of International Finance. Available in: www.iif.com.

International Monetary Fund. International Financial Statistics. Edition: August, 2001

International Monetary Fund. World Economic Outlook Database. Edition: September, 2011. Available in: http://www.imf.org/external/pubs/ft/weo/2011/02/weodata/index.aspx>.

International Monetary Fund. Liberalizing Capital Flows and Managing Outflows Background Paper. March 16, 2012a. Available in: https://www.imf.org/external/np/pp/eng/2012/031612.pdf>.

International Monetary Fund.The Liberalisation and Management of Capital Flows: An Institutional View (Washington: International Monetary Fund). 2012b.

Jeanne, O. (2012). “Capital Flow Management." American Economic Review Papers and Proceedings (May): 203-06.

Klein, M. (2012). "Capital Controls: Gates and Walls". Brookings Papers on Economic Activity, September.

Kose, M. A. et al. (2006). "Financial Globalization: A Reappraisal." IMF Working Paper 06/189.

Kregel, J. A. (1998). Yes, "it" did happen again: a minsky crisis happened in Asia. New York: Jerome Levy Economics Institute, 19 p. (Working papers, 234).

Kregel, J. A. (2014)."Can we create a stable international financial environment that ensures net resource transfers to developing countries?", Journal of Post Keynesian Economics, M.E. Sharpe, Inc., vol. 26(4), p. 573-590.

Kregel, J. (2009). "The global crisis and the Implications for Developing Countries and the BRICS". Public Policy Brief, n. 102.The Levy Economics Institute of Bard College.

Kregel, J. (2014). "Minsky and dynamic macroprudential regulation". PSL Quarterly Review, Economia Civile, vol. 67(269), p. 217-238.

Ma, G.; McCauley, R. (2008). “Efficacy of China's Capital Controls: Evidence from Price and Flow Data", Pacific Economic Review 13:1, 104-123.

Magud, N.; Reinhart, C. M. (2006). "Capital Controls: an Evaluation". NBER Working Paper 11973.

Ministério das Relações Exteriores. BRICS - Agrupamento Brasil, Rússia, Índia, China, África do Sul. Available in: <http://www.itamaraty.gov.br/temas/mecanismos-interregionais/agrupamento-brics>.

Minsky, H. P. (1986). Stabilizing an unstable economy. Yale University Press.

Minsky, H. P. (1982). "Can "it" happen again?", Essays on instability \& finance. Armonk; New York: M.E.Sharpe.

Mitchell, W. (2010). “Are capital controls the answer?"Available in: $<$ http://bilbo.economicoutlook.net/blog/?p=9401>.

Mohamed, S. "The Impact of International Capital Flows on the South Africa Economy Since The End of Apartheid." Fall, 2006. 
O’Neill, J. (2001). "Building Better Global Economic BRICs." Global Economics Paper 66. Goldman Sachs. Economic Research Group, November 30.

Ostry, J.; Ghosh, A.; Habermeier, K.; Chamon, M.; Qureshi, M.; Reinhardt, D. (2010). "Capital Inflows: The Role of Controls". IMF Staff Position Note. February 19. International Monetary Fund.

Paula, L. F. R.; Ferrari Filho, F. (2006). "Regime cambial, conversibilidade da conta de capital e performance econômica: a experiência recente do Brasil, Rússia, Índia e China". In: João Sicsú; Fernando Ferrari Filho. (Org.). Câmbio e Controles de Capitais: avaliando a eficiência de modelos macroeconômicos. Rio de Janeiro: Elsevier-Campus, p. 184-221.

Paula, L.F.; Alves JR., A. J. (2000). "External financial fragility and the 1998-1999 Brazilian currency crisis". Journal of Post Keynesian Economics, Armonk, v.22, n.4, p. 598-617. Paula, L. F.; Barcelos, F. C. (2011). "Liberalização financeira, estabilidade macroeconômica e crescimento econômico nos países do BRIC". In: Revista de Economia Política, São Paulo, vol.31, no 5.

Plihon, D. (1995). "A ascensão das finanças especulativas". Economia e Sociedade, Campinas, v. 5, n. 5, p. 61-78.

Prates, D. M. (2005). "As assimetrias do sistema monetário e financeiro internacional". Revista de Economia Contemporânea, 9(2): p. 263-288.

Shah, A.; Patnaik, I. (2005). "India's Experience with Capital Flows: The Elusive Quest for a Sustainable Current Account Deficit". NBER Working Papers 11387.

Sobeet. World Investment Report 2012: Rumo à nova geração de políticas de investimento. Sociedade brasileira de estudos de empresas transnacionais e da globalização econômica. São Paulo, Brazil. 2012.

Tonveronachi, M. (2006). "Foreign debt and financial fragility in the perspective of the emerging countries", Quarterly Review (Banca Nazionale del Lavoro), Rome, v. 58, n. 236, p. 23- 48.

Unctad. World Investment Report: Transnational Corporations and Infrastructure Challenges. New York and Genova, 2008.

Wolfson, M. H. (2002). "Minsky's theory of financial crisis in a global context". Journal of Economic Issues, 36, 393

Zhang, M. (2011). "China's Capital Control: Stylized Facts and Referential Lessons", In: Task Force on Managing Capital Flows for Long-run Development, Boston; 09/2011. 
ANNEX 1 - Unit Root Test: ADF test (Augmented Dickey-Fuller)

Table I: Unit root test for financial sub-accounts of

Brazil - 2000 to 2010

\begin{tabular}{|c|c|c|c|c|c|}
\hline Variable & Lag & Constant & Trend & t-ADF & t-probit \\
\hline Portfolio Investment & 0 & yes & yes & -3.841490 & 0.0237 \\
\hline Direct Investment & 1 & yes & yes & -4.114853 & 0.0122 \\
\hline Derivatives & 0 & yes & yes & -4.280017 & 0.0078 \\
\hline Other Investment & 0 & yes & yes & -5.229331 & 0.0006 \\
\hline \multicolumn{6}{|c|}{ China (Hong Kong) - 2000 to 2010} \\
\hline Variable & Lag & Constant & Trend & $t-A D F$ & t-probit \\
\hline Portfolio Investment & 0 & yes & yes & -8.268014 & 0.0000 \\
\hline Direct Investment & 0 & yes & yes & -7.875031 & 0.0000 \\
\hline Derivatives & 0 & yes & yes & -10.24336 & 0.0000 \\
\hline Other Investment & 0 & yes & yes & -7.054478 & 0.0000 \\
\hline \multicolumn{6}{|c|}{ India - 2000 to 2010} \\
\hline Variable & Lag & Constant & Trend & t-ADF & t-probit " \\
\hline Portfolio Investment & 0 & yes & yes & -4.462485 & 0.0048 \\
\hline Direct Investment & 0 & yes & yes & -3.804173 & 0.0259 \\
\hline Derivatives & - & - & - & - & - \\
\hline Other Investment & 0 & yes & yes & -4.650564 & 0.0029 \\
\hline & Russia & -2000 to 2010 & & & \\
\hline Variable & Lag & Constant & Trend & t-ADF & t-probit \\
\hline Portfolio Investment & 0 & yes & yes & -4.125163 & 0.0117 \\
\hline Direct Investment & 0 & yes & yes & -7.177858 & 0.0000 \\
\hline Derivatives & 0 & yes & yes & -4.868612 & 0.0016 \\
\hline Other Investment & 0 & yes & yes & -6.278179 & 0.0000 \\
\hline & uth Af & ica -2000 to 20 & 010 & & \\
\hline Variable & Lag & Constant & Trend & t-ADF & t-probit \\
\hline Portfolio Investment & 0 & yes & yes & -4.760630 & 0.0021 \\
\hline Direct Investment & 0 & yes & yes & -6.034128 & 0.0001 \\
\hline Derivatives & - & - & - & - & - \\
\hline Other Investment & 0 & yes & yes & -6.069938 & 0.0000 \\
\hline
\end{tabular}


ANNEX 2 - ARCH test: conditional heteroskedasticity

Table II: ARCH test for financial sub-accounts of

Brazil - 2000 to 2010

\begin{tabular}{|c|c|c|}
\hline Variable & F-statistic & t-probit \\
\hline Portfolio Investment & 6.246848 & 0.0165 \\
\hline Direct Investment & 42.04613 & 0.0000 \\
\hline Derivatives & 4.452874 & 0.0410 \\
\hline Other Investment & 3688.959 & 0.0000 \\
\hline \multicolumn{3}{|c|}{ China (Hong Kong) - 2000 to 2010} \\
\hline Variable & F-statistic & t-probit \\
\hline Portfolio Investment & 100.2567 & 0.0000 \\
\hline Direct Investment & 121452.5 & 0.0000 \\
\hline Derivatives & 39.52695 & 0.0000 \\
\hline Other Investment & 640.2960 & 0.0000 \\
\hline \multicolumn{3}{|c|}{ India - 2000 to 2010} \\
\hline Variable & F-statistic & t-probit \\
\hline Portfolio Investment & 14.62467 & 0.0004 \\
\hline Direct Investment & 33.89904 & 0.0345 \\
\hline Derivatives & - & - \\
\hline Other Investment & 43.55594 & 0.0000 \\
\hline \multicolumn{3}{|c|}{ Russia - 2000 to 2010} \\
\hline Variable & F-statistic & t-probit \\
\hline Portfolio Investment & 4.193784 & 0.0470 \\
\hline Direct Investment & 3938.465 & 0.0000 \\
\hline Derivatives & 4.155990 & 0.0480 \\
\hline Other Investment & 1234.032 & 0.0000 \\
\hline \multicolumn{3}{|c|}{ South Africa - 2000 to 2010} \\
\hline Variable & F-statistic & t-probit \\
\hline Portfolio Investment & 825.1906 & 0.0000 \\
\hline Direct Investment & 105.1531 & 0.0000 \\
\hline Derivatives & - & - \\
\hline Other Investment & 1971.755 & 0.0000 \\
\hline
\end{tabular}

Source: own elaboration. 
ANNEX 3 - Series of data on capital flows

Table 3 - Data

\begin{tabular}{|c|c|c|c|c|c|c|c|c|c|c|c|c|c|c|c|c|c|c|c|c|}
\hline \multirow[b]{2}{*}{ Period } & \multicolumn{4}{|c|}{ Brazil } & \multicolumn{4}{|c|}{ China } & \multicolumn{4}{|c|}{ India } & \multicolumn{4}{|c|}{ Russia } & \multicolumn{4}{|c|}{ South Africa } \\
\hline & DI & PI & Der & OI & DI & PI & Der & OI & DI & PI & Der & OI & DI & PI & Der & OI & DI & PI & Der & OI \\
\hline 2000Q1 & 6643,622 & 3209,238 & $-39,0722$ & $-1504,64$ & 1179,42 & 7891,406 & $-4873,92$ & $-7181,72$ & 642,6607 & 1328,23 & 0 & 2201,019 & $-155,605$ & 620,5204 & 0 & $-8288,71$ & 688,1636 & $-642,78$ & $-46,8085$ & $-645,322$ \\
\hline 2000Q2 & 6034,389 & 1135,298 & 6,1068 & $-2026,01$ & 7457,69 & 841,5 & 2251,703 & $-7545,3$ & 924,263 & 789,113 & 0 & $-90,023$ & 2,81 & $-1521,25$ & 0 & $-3190,75$ & $-616,65$ & $-859,723$ & 33,39152 & 2452,75 \\
\hline 2000Q3 & 8235,78 & 2138,51 & $-108,01$ & $-2801,27$ & 3041,3 & 1070,07 & $-145,44$ & $-145,32$ & 803,908 & 396,0138 & 0 & 312,631 & $-287,5$ & $-11749,2$ & 0 & $-3340,48$ & 902,148 & 212,006 & $-52,7146$ & 40,57 \\
\hline 2000Q4 & 9583,862 & 472,006 & $-56,411$ & $-1547,22$ & $-9106,7$ & 14682,3 & 2972,939 & $-8224,61$ & 703,856 & $-168,137$ & 0 & 2495,67 & $-22,25$ & $-569,79$ & 0 & $-5792,42$ & $-282,009$ & $-573,887$ & $-75,7989$ & $-460,057$ \\
\hline 2001Q2 & 7465,46 & $-716,326$ & $-189,764$ & 1181,69 & 5160,68 & $-4530,01$ & 1645,3 & -1744 & 808,055 & 934,9115 & 0 & $-1615,26$ & 16,899 & $-14,331$ & 0 & $-1693,94$ & 11616,37 & $-8005,69$ & 0 & $-3207,13$ \\
\hline 2001Q3 & 5068,019 & 1678,136 & $-40,835$ & \begin{tabular}{|l}
$-3914,57$ \\
\end{tabular} & 947,85 & $-10562,7$ & 3248,76 & $-1186,8$ & 1292,894 & 215,8348 & 0 & 358,738 & 16,276 & $-300,669$ & 0 & 9033,63 & 436,7246 & $-330,233$ & 0 & 0,717 \\
\hline 2001Q4 & 7563,991 & $-3368,79$ & $-129,988$ & $-2104,55$ & $-760,07$ & $-11911,9$ & 1108,04 & 7556,8 & 1132,807 & 129,0169 & 0 & 2066,14 & 408,939 & $-531,369$ & 0 & $-3396,97$ & $-553,586$ & $-334,053$ & 0 & 669,379 \\
\hline 2002Q1 & 4192,327 & 2447,308 & 275,187 & $-1669,67$ & 654,06 & 531,6 & 55,04 & 228,1 & 500,136 & 671,9646 & 0 & 1054,974 & 179,319 & 589,3054 & $-0,985$ & $-5601,87$ & 792,396 & $-146,714$ & 0 & $-715,437$ \\
\hline 2002Q2 & 4415,537 & $-1542,83$ & $-92,623$ & 871,18 & 5088,98 & $-14510,2$ & 3130,15 & 6151,17 & 1239,984 & $-262,866$ & 0 & $-318,013$ & $-110,859$ & $-140,263$ & $-0,938$ & 585,29 & 882,069 & 1351,036 & 0 & $-2434,35$ \\
\hline 2002Q3 & 1784,53 & $-3778,21$ & 52,114 & $-5608,55$ & $-4763,43$ & $-11260,3$ & 827,28 & 11190,51 & 532,12 & $-131,075$ & 0 & 2761,209 & 487,673 & 663,1265 & 2,734 & 2861,95 & 515,856 & $-1310,63$ & 0 & 77,896 \\
\hline 2003Q1 & 1281,195 & 999,144 & $-18,744$ & $-2084,17$ & 1155,71 & $-8471,58$ & 1251,24 & 4586,97 & 769,079 & 593,031 & 0 & 717,167 & 848,39 & $-3208,91$ & 107,493 & 485,39 & $-306,695$ & $-578,861$ & 0 & 1200,763 \\
\hline 2003Q2 & 1562,894 & 2901,901 & $-52,228$ & \begin{tabular}{|l|}
$-3892,82$ \\
\end{tabular} & 470,485 & $-3288,91$ & 6848,64 & $-11359,4$ & 386,108 & 1375,92 & 0 & 3920,79 & 777,64 & $-2670,12$ & 47,36 & 4610,438 & 149,7505 & 2904,309 & 0 & $-2360,76$ \\
\hline 2003Q3 & 3399,434 & $-252,471$ & $-108,938$ & \begin{tabular}{|l}
$-5126,99$ \\
\end{tabular} & 6077,11 & -10972 & 447,93 & $-4219,96$ & 701,907 & 2136,16 & 0 & 2205,94 & $-717,23$ & $-2235,64$ & 123,187 & $-3047,8$ & 89,643 & $-611,728$ & 0 & $-390,923$ \\
\hline 2003Q4 & 3650,707 & 1658,958 & 28,913 & $-4103,32$ & 429,07 & $-11267,6$ & 1499,29 & 860,4 & 587,046 & 4111,08 & 0 & $-1083,32$ & $-2677,79$ & 3605,809 & 362,352 & 6613,36 & 297,895 & $-990,306$ & 0 & $-1364,46$ \\
\hline 2004Q1 & 2387,254 & 2385,118 & 50,597 & \begin{tabular}{|l}
$-2330,67$ \\
\end{tabular} & \begin{tabular}{|l|}
$-13798,1$ \\
\end{tabular} & $-21506,6$ & 1635,72 & 35248,83 & 713,185 & 3732,98 & 0 & $-2052,02$ & 595,1 & 2478,69 & $-36,616$ & $-5176,08$ & 1305,072 & 720,3147 & 0 & $-144,83$ \\
\hline 2004Q2 & 838,057 & $-6085,86$ & $-290,665$ & 3418,51 & 3058,23 & $-16765,7$ & 1152 & 9015,6 & 963,112 & 155,915 & 0 & 2545,43 & 486,507 & $-1626,61$ & $-186,455$ & $-6219,64$ & $-1722,95$ & 2164,346 & 0 & 1175,205 \\
\hline 2004Q3 & 330,14 & $-526,9$ & $-294,385$ & $-3834,48$ & $-11914,4$ & -8067 & 761,6 & 8229,56 & 1334,082 & 464,046 & 0 & 1750,026 & $-2117,26$ & 696,794 & 34,53 & $-6438,78$ & 254,9818 & 259,996 & 0 & $-428,313$ \\
\hline 2004Q4 & 5139,453 & $-522,492$ & $-142,964$ & $-3853,7$ & 10971,16 & 7006,85 & 2143,53 & $-27264,8$ & 581,822 & 4684,137 & 0 & 7356,14 & 2698 & $-925,995$ & 88,933 & 10520,83 & $-441,111$ & 3214,158 & 0 & 1038,51 \\
\hline 2005Q1 & 2545,849 & 5816,894 & 91,6764 & 230,151 & 4756,71 & $-7948,02$ & 1569,06 & $-3904,3$ & 834,391 & 3982,998 & 0 & 3369,84 & 1399,71 & $-3203,25$ & $-89,703$ & 1801,2 & 99,586 & 1650,605 & 0 & 3499,89 \\
\hline 2005Q2 & 4186,419 & $-1315,75$ & 97,863 & $-4841,59$ & 2733,69 & $-18124,1$ & 857,21 & 9545,58 & 1350,546 & 972,146 & 0 & 3451,24 & 3598,3 & 2073,55 & $-153,976$ & $-6823,56$ & 1246,073 & 3460,035 & 0 & 676,306 \\
\hline
\end{tabular}




\begin{tabular}{|c|c|c|c|c|c|c|c|c|c|c|c|c|c|c|c|c|c|c|c|c|}
\hline 2005Q3 & 2539,407 & $-153,361$ & $-28,2$ & \begin{tabular}{|l}
$-5810,22$ \\
\end{tabular} & $-4055,01$ & $-4051,7$ & 183,29 & 1558,81 & 1075,943 & 4441,1 & 0 & 5026,34 & 3663,18 & $-3712,2$ & $-6,273$ & $-654,41$ & 4075,699 & 809,513 & 0 & $-3543,71$ \\
\hline 2005Q4 & 3277,904 & 536,755 & $-201,294$ & 6171,6 & 2981,43 & $-1342,87$ & 1310,88 & $-7518,4$ & 1367,767 & 2747,87 & 0 & $-3336,25$ & $-8542,86$ & $-6537,16$ & 16,99 & 18195,2 & 191,33 & $-1112,8$ & 0 & 1561,832 \\
\hline 2006Q1 & 826,45 & 6639,498 & 174,1799 & $-3607,83$ & 3316,9 & 7858,83 & 159,46 & $-13109,8$ & $-759,87$ & 4333,11 & 0 & 4801,101 & 2798,04 & $-4730,9$ & 4,053 & $-5111,6$ & 1104,014 & 8107,995 & 0 & $-4415,9$ \\
\hline 2006Q2 & 2056,64 & $-7358,61$ & 44,3334 & 6562,2 & $-5306,01$ & $-5400,75$ & 1625,75 & 6052,3 & 1738,26 & $-506,039$ & 0 & 9493,33 & 5898,69 & 3683,36 & $-41,764$ & 6033,24 & \begin{tabular}{|l}
$-658,629$ \\
\end{tabular} & 4899,981 & 0 & 1593,52 \\
\hline 2006Q3 & 1217,38 & 3215,012 & 17,4816 & $-1993,21$ & $-2407,81$ & $-3697,25$ & 898,63 & $-2939,7$ & 2115,79 & 2149,86 & 0 & 3594,32 & 1802,8 & 14933,2 & $-62,205$ & $-31508,9$ & $-5454,34$ & 2924,329 & 0 & 4321,09 \\
\hline 2006Q4 & $-13520,71$ & 7077,327 & 147,1816 & 13615,73 & 4472,2 & $-25473,3$ & 653,95 & 12675,3 & 2898,12 & 3568,791 & 0 & 4347,94 & $-3949,1$ & 1816,74 & 0,511 & 11504,6 & $-1103,48$ & 3695,103 & 0 & 321,972 \\
\hline 2007Q2 & 15776,31 & 14679,72 & $-136,708$ & 5482,2 & $-419,67$ & $-7048,89$ & 2100,78 & 1052,1 & 2874,06 & 7542,008 & 0 & 5280,54 & $-10147,3$ & 5795,93 & $-99,609$ & 52913,15 & $-247,79$ & 5027,337 & 0 & 646,63 \\
\hline 2007Q3 & 7002,634 & 11454,79 & $-217,208$ & \begin{tabular}{|l}
$-6525,27$ \\
\end{tabular} & $-544,7$ & 3174,63 & 917,76 & $-12253,4$ & 2265,76 & 10900,43 & 0 & 20057,74 & 302,95 & 3550,58 & 79,405 & $-1365,2$ & 1672,371 & 2795,406 & 0 & 1865,15 \\
\hline 2007Q4 & $-3762,5$ & 12808,01 & $-245,16$ & 7477,46 & $-4951,2$ & 1758,6 & 13,38 & 4770,3 & 2120,5 & 12726,74 & 0 & 14792,55 & 6908,28 & 4393,81 & 329,69 & 23991,2 & 1095,808 & $-947,157$ & 0 & 4716,961 \\
\hline 2008Q1 & 4346,07 & 5651,845 & \begin{tabular}{|l}
$-195,088$ \\
\end{tabular} & 12383,09 & 4730,8 & $-24273,9$ & 2830,22 & 17632,69 & 8632,66 & $-3735,98$ & 0 & 23126,87 & 4612 & $-5079,62$ & 252,68 & $-20246,3$ & 5264,829 & \begin{tabular}{|l}
$-2937,22$ \\
\end{tabular} & 0 & 5771,25 \\
\hline 2008Q2 & 3785,09 & 7640,427 & $-185,159$ & 6398,54 & $-7628,4$ & 10051,98 & 698,6 & $-6421,82$ & 9196,75 & $-4206,85$ & 0 & 452,27 & 6230,6 & 399,24 & $-5,19$ & 28325,2 & 441,138 & 1402,765 & 0 & 1133,585 \\
\hline 2008Q3 & 7316,78 & 3794,324 & $-21,206$ & 2485,7 & 5706,29 & 26191,9 & 3940 & $-39288,1$ & 5610,14 & -13 & 0 & 2042,5 & 5505,1 & -965 & $-401,23$ &, 1 & 242 & 37 & 0 & 13 \\
\hline 2009Q1 & 5734,821 & $-2919,34$ & 203,8806 & 199,38 & 271,07 & 5221,72 & 250,4 & $-3993,1$ & 4299,79 & $-2692,14$ & 0 & $-1250,84$ & $-4011,6$ & $-9897,44$ & $-3051,67$ & $-15547,7$ & 1091,202 & 886,8669 & 0 & $-1215,64$ \\
\hline 2009Q2 & 8728,76 & 4315,91 & 8,4035 & 1838 & $-4031,7$ & -30655 & 1944,2 & 43015,39 & 4827,31 & 8268,03 & 0 & $-9437,15$ & $-1726,25$ & $-383,79$ & $-314,04$ & 5601,51 & 2348,432 & 3469,195 & 0 & $-2662,11$ \\
\hline 2009Q3 & 8376,98 & 20156,02 & \begin{tabular}{|l}
$-42,9868$ \\
\end{tabular} & $-8110,95$ & $-4805,89$ & $-7137,07$ & 179,59 & 20154,75 & 7502,66 & 9676,885 & 0 & 7274,04 & 2932,8 & 1662,64 & 134,82 & $-19243,4$ & 783,724 & 3049,67 & 0 & 4284,4 \\
\hline 2009Q4 & 13192,25 & 28730,52 & $-13,0651$ & \begin{tabular}{|l}
$-10238,4$ \\
\end{tabular} & $-3032,5$ & $-10318,9$ & 794,35 & 38289,3 & 3039,02 & 5684,602 & 0 & 5903,943 & $-4360,3$ & 6439,17 & $-12,9$ & 10129,99 & $-180,971$ & 4216,23 & 0 & 205,2602 \\
\hline 2010Q1 & $-586,7$ & 8212,79 & \begin{tabular}{|l}
$-25,5389$ \\
\end{tabular} & 11585,82 & $-1598,4$ & $-11023,9$ & 995,41 & 7945,86 & 3402,49 & 8766,101 & 0 & 3637 & $-2249,48$ & 2333,376 & $-805,08$ & $-11187,3$ & 430,0566 & 5121,133 & 0 & $-2585,8$ \\
\hline 2010Q2 & 3801,74 & 14577,27 & 8,5284 & 4882,5 & 1658,9 & $-12992,7$ & 1385,39 & 10719,11 & 2916,59 & 4605,356 & 0 & 9029,26 & $-2048,8$ & 6782,71 & $-1246,14$ & 5095,55 & $-60,169$ & 3468,473 & 0 & 797,841 \\
\hline 2010Q3 & 13413,27 & 19745,64 & $-18,8041$ & $-3901,6$ & $-3873,4$ & -13595 & 812,6 & 9760,9 & 2582,42 & 19192,48 & 0 & $-472,39$ & $-3181,34$ & 438,99 & 641,03 & $-4551,1$ & $-803,34$ & 4938,51 & 0 & 1186,355 \\
\hline 2010Q4 & 20290,6 & 20475,2 & $-76,3332$ & $-13840,9$ & $-3365,5$ & -23261 & 558,7 & 22099,5 & 2106,66 & 6297,92 & 0 & 6473,562 & $-2127,9$ & $-10953,6$ & $-363,1$ & $-3226,14$ & 1617,214 & $-3057,75$ & 0 & $-676,93$ \\
\hline
\end{tabular}

Source: own elaboration.

Note: $\mathrm{DI}=$ direct investment, $\mathrm{PI}=$ portfolio investment, $\mathrm{DER}=$ derivatives and $\mathrm{OI}$ = other investment. 